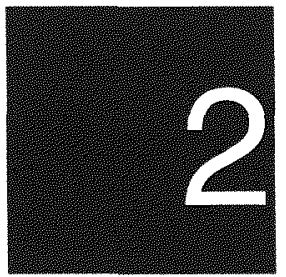

\title{
Social change in the Porgera Valley
}

\section{Susanne Bonnell}

This chapter is based on the observations which I made during my period of employment with the Porgera Joint Venture (PJV), from February 1989 to October 1991, and an additional 11-week period of fieldwork in the Porgera area between October 1992 and May 1993, conducted as part of the Porgera Social Monitoring Programme. According to the terms of reference established for my own contribution to this programme, I was to

- describe and provide information on the changes which took place in the social environment of the Porgera mine impact area from the end of 1988 to the present (i.e. to mid 1993)

- identify undesirable impacts and trends and where possible recommend strategies to eliminate or minimise these impacts and trends; and

- identify existing and potential resources in the community, government and PJV which could be utilised for long term social development strategies for the mine impact area.

Fourteen separate components of the Porgera social environment were simultaneously identified as the objects of my study, from 'relocation and settlement patterns' through to 'socially disruptive influences'.

My study is thus concerned with the processes of social change from the beginning of 1989 to mid 1993. Although the Special Mining Lease (SML) was not granted until May 1989, the building and 
occupation of the relocation houses which were provided to many of the local landowners really marks the beginning of the construction phase of the Porgera mine. My study of the history and impact of the relocation programme itself turned out to be a major component of the report which I presented to the company, and the findings of this study are presented as a separate chapter of this monograph (see Chapter 4). It should also be noted that my own study was primarily concerned with the social rather than the economic impact of the mine, because my fellow consultant, Glenn Banks, had been commissioned to produce a separate study of the economic impact (see Chapters 3, 5 and 7). The main areas of overlap between our studies are those which concern the impact of development on subsistence agriculture and the impact of outsiders on the Ipili people of the Porgera Valley. At the same time, Banks is more concerned with the way that social and economic impacts were seen from the male point of view, while my own study tends to emphasise the female viewpoint. This difference is understandable and arguably appropriate. Although both sexes were concerned with the full range of socioeconomic considerations, women were more concerned with matters affecting the family and the community, while men were more concerned with economic gains and losses.

The main sources of information for my study were government and PJV records, interviews with individuals and groups, a relocation survey and a separate survey on the marriages of those who had been relocated. The two-volume 1987 Pacific Agribusiness report-Social and Economic Impact Study: Porgera gold mine (hereafter referred to as the SEIS)-Was to be used as the baseline study. Besides the SEIS, I reviewed a number of other reports which discussed the local social environment prior to construction of the mine, notably those of Talyaga (1984), Jackson (1987), and Robinson (1988, 1991).

Both company officials and public servants in Porgera were very cooperative (and patient) in providing access to documents which might contain information relevant to this study. The main problem was trying to collect data on health, education and crime. There were virtually no government records in Porgera prior to 1991 containing any meaningful information. The situation improved with the 1991 Annual Report for Porgera District and the 1992 Annual Report was even more comprehensive. The Porgera Development Authority (PDA) records appeared to be complete and accurate. Due to protocol problems, however, I was forbidden access to provincial government 
statistics on health and education in Wabag and told not to interview provincial public servants located there. By the time this problem was sorted out, the buildings which would have contained this information had been destroyed by the fire which followed the suspension of the Enga Provincial Government. Police in Wabag kept no crime statistics. I was never able to find out if the data I was looking for existed or not. Fortunately the very informative Enga Six Year Education Plan (1992-97), written in 1991, had been widely distributed. Otherwise, the search for the elusive data which should have existed as part of the standard national data collection system (I was not looking for state secrets) was time consuming and frustrating.

Apart from the survey interviews conducted in the relocation houses (see Chapter 4), I interviewed a wide variety of other individuals, including public servants, PJV employees, church leaders, school teachers and heads of various organisations. I attempted to seek out as wide a range of opinion as possible. Those with anti-mine sentiments appeared to speak quite frankly. My visits coincided with those of Father Phil Gibbs (a well-known Catholic priest who had done genealogical work in the area) and Chris Ballard (a researcher from the Australian National University in Canberra) who gave me some very interesting insights into the evolutionary context of certain changes occurring in Porgera.

A study of this kind necessarily has serious limitations. The broad terms of reference combined with a one-person research approach means that a lot of areas were not investigated or were incompletely investigated. It is hoped that the breadth of my study does something to compensate for its lack of depth. I have tried to show the various ways in which the development of the mine had either directly or indirectly introduced social benefits and social costs. The presence of the mine may also have accelerated social trends which were already present. However, it must also be stressed that many of the social problems identified in this study were not unique to Porgera-they were national problems. These included: a high birth rate which showed no sign of decreasing; the large percentage of population under the age of 15, which put further stress on the already stressed health and education systems; an increasing law and order problem; the breakdown of clan discipline; trade stores; alcohol abuse; and domestic violence. My original report to the PJV contained a long list of recommendations which were intended to spark discussion and debate between Porgerans themselves and the staff of relevant 
national and provincial government agencies, as well as those of the mining company, which might lead to an improvement in the socioeconomic situation of Porgera District and Enga Province. These recommendations have not been included in the published version of the report, in case they serve to embarrass some of the relevant stakeholders, but the reader will not find it difficult to infer their general character from the findings presented here.

\section{The Ipili of Porgera}

This brief sketch is intended to highlight aspects of Ipili culture and the impact of events since foreign intrusion in 1938. While the development of the mine has led, either directly or indirectly, to considerable change in Ipili society, change and adaptation have always been a feature of any existing culture. Prior to European intrusion, Ipili society would have been adapting to changes resulting from trade, warfare, disease and famine. Although Pacific Agribusiness (1987), Gibbs (1977), Meggitt (1957) and Biersack (1980, $1982,1987,1991)$ have written at greater length and depth about aspects of Ipili culture, there is still a need for a more comprehensive anthropological study of the Ipili of Porgera.

\section{Environment and culture}

The Ipili are a cultural and linguistic group located in two census divisions of the Porgera District of Enga Province. The Eastern Ipili of Porgera occupy land of a generally higher elevation than the Western Ipili of Paiela. The disadvantage of malaria prevalent in the Paiela area is offset by the less productive land of the Porgera area.

The Porgera Valley is characterised by steep mountains at altitudes ranging from about 1,800 to $3,500 \mathrm{~m}$. Soil fertility is variable, but generally of poor quality compared with the rest of Enga Province. Both the altitude and soil fertility limit the types of crops which can be grown. Porgera has an average annual rainfall of about $3,500 \mathrm{~mm}$, with no marked dry season. This high rainfall is linked to extensive cloud cover, particularly at higher altitudes (see Chapter 5). The high rainfall often leads to soil saturation and landslides. The average daily temperature of $11-22^{\circ}$ celsius varies little throughout the year. The Porgera Valley is also characterised by low wind speeds, and there have been no reported frosts in the area.

The origins and length of occupation of the Ipili are not known. It has been suggested that the Ipili originated from migrations westward 
from Enga and northwards from the Tari basin. While there are many similarities with their neighbours, there are also striking differences in terms of kinship, land tenure, beliefs and ceremonies.

The Ipili practise a form of cognatic kinship in which individuals trace their descent through both male and female links to a founding ancestor (Burton 1991:10). An Ipili is therefore a member of many descent groups. This form of kinship offers a great deal of flexibility for land usage rights. As the Ipili were subsistence horticulturalists, this would be particularly advantageous where soil fertility is poor. On the other hand, cognatic kinship divides an individual's loyalties between various descent lines. This reduces the possibilities for a strong clan leadership system, and tends to fragment society into smaller groups. Leadership, as in other parts of the highlands, is achieved as opposed to inherited. The Ipili had male leaders who were big men, akali andane, and wise men, nembo yene. These leaders had accrued wealth, spoke well, interpreted events, and advised on the best course of action. But the outside influences of cash and education has led to a conflict between traditional values and new forces (Pacific Agribusiness 1987[1]:19). Today, the road to becoming a big man is through success in business or politics or, as is usual in PNG, the combination of both.

\section{Recent history}

European intrusion into Porgera has mainly been from three sectors: mining, government and Christian missions. It was generally accepted that Porgera's first contact with the outside world was the Taylor/Black patrol of 1938. Banks (Chapter 3) suggests that the first European intruders were the Fox brothers on an 'unauthorised expedition' in 1934. Gibbs (1977:11) reports that the arrival of James Taylor and John Black had a profound impact on the Ipili of Porgera

Older men told me of their fearful reactions when they first witnessed the arrival of the 'redmen'. The 'redmen' were immediately thought to be yama or spirits and women and children were sent to hide in the forests while some of the men killed pigs as propitiatory offerings. Aircraft were used for reconnaissance in conjunction with the patrol and people told me how fearful they were of these noisy flying objects. Men also told me that several people were shot and killed by the patrol.

Although the Taylor/Black Hagen-Sepik patrol was a government exploration patrol, gold prospecting also featured as part of the 
patrol's activities. It was during this patrol that gold colours were found in the Porgera River. John Black wrote in his diary on 31 March 1939, 'After finding gold today I am not elated but rather awed with the dangers of wealth if it should turn out to be wealth' (Handley 1993:3). Although Black was of course referring to himself, it was somewhat prophetic in view of the future impact of gold wealth on the lives of the Ipili.

The next recorded impact on the Ipili was the cult from Lyeimi about 1942 (Meggitt 1957; Gibbs 1977). A Taro Enga prophet appeared preaching change, and carried the message that the earth was going to end and the people who practised the new way of life would go to live in the sky. This millenarian cult paved the way for the acceptance of Christian missionaries who carried a similar message.

After World War II, and while the Ipili were still under the influence of the Lyeimi cult, the first gold prospectors entered the Porgera Valley. Jim Taylor, who was then a District Officer in the Central Highlands, issued permits to enter Porgera to Joe Searson, Mick and Jim Leahy, Elphinstone and John Black. This expedition ran out of supplies and failed to find gold. Joe Searson remained behind in 1946 and settled among the Ipili people. There was a minor gold rush in 1948, which resulted in a number of European miners seeking their fortune (Pacific Agribusiness 1987[1]:6). The Ipili were introduced to a cash economy by these early prospectors, and they purchased goods at a local trade store which was opened by Jim Taylor, who also had mining leases in the area. The Ipili learned the skills to become alluvial miners themselves.

During the 1950s, Catholic and Lutheran missionaries made regular patrols to Porgera. Shortly after Porgera was de-restricted in 1962, the first permanent Christian mission stations were established. Catholic missionaries acquired land for their stations at Mungalep and Tipinini (see Map 1.1). Lutheran missionaries acquired land at Yuyan, then located near the government's patrol post and airstrip, which had both been established in 1961. Apostolic missionaries took out leases at Anawe and Ingau, and the Seventh Day Adventists at Yendakali and Kairik. Missionaries played an important role in the early social and economic development of Porgera. They introduced new vegetables and cash crops, built roads, promoted cash cropping and sawmilling, and established schools and health facilities (Pacific Agribusiness 1987[1]:7).

In the 1960s, mining leases were granted to companies for exploration. Companies involved in early exploration included Bulolo Gold Dredging, which was amalgamated with Placer in 1966, Mount 
Isa Mines, Anaconda Australia, and Ada Explorations. In 1972, the four-wheel-drive vehicular track reached Porgera from Laiagam. This led to further intrusions and influences from the outside world, and no doubt assisted in the intensification of local mining activities in the 1970s. Initial involvement of the Ipili in alluvial mining began when they were hired as labourers for the colonial gold works. Later, Ipili alluvial gold miners worked on existing leases on a tribute basis, sharing profits with expatriate leaseholders. This tribute system lapsed in 1983, after a major gold strike at Waruwari triggered a gold rush. By this time, Yuyan had become a major informal gold buying centre, and Ipili miners panned gold which they sold directly to official or unofficial buyers. Gold became known as the 'second garden' for the Ipili.

In 1988 there was a major, and totally Melanesian, gold rush at Mount Kare, only a day's walk from Porgera. Here many Ipili from both Porgera and Paiela made and lost fortunes. The events of Mount Kare will no doubt become legends to occupy night time story-telling in Ipili households for years to come.

\section{The Ipili and the Porgera Mine}

By 1993, the development of the Porgera mine could already be broken down into five stages, each of which could be characterised by different attitudes and responses to change, particularly from the SML landowners as well as the wider community. ${ }^{1}$

The exploration stage lasted until about 1987 . The change from individual prospectors to company mining leases and the escalation of exploration activity were relatively gradual and benign. Porgerans benefited from increased employment and trade. Knowledge was increased, producing a greater desire for the perceived benefits of the outside world. This change was easily absorbed and the gains exceeded the costs. Mining activity injected some cash into the economy primarily in the form of wages and some compensation. Profits from alluvial mining were an important source of cash.

In the pre-construction stage, from 1987 to mid 1989, the possibility of a mine became a reality. Tension increased in the community. Different vested interest groups, both within and without the SML and Porgera District, jockeyed for support and negotiated for benefits, often exacerbating the unrealistic expectations of benefits to be acquired. Landowners shifted, built, and planted to increase their chances for compensation. Disputes over land boundaries escalated, as did conflicts between the young and the old for leadership. In 1988, 
tension was defused to a certain degree by the Mount Kare gold rush, which divided the energies of many SML landowners and offered alternative possibilities for non-SML landowners. In Porgera itself, preparations for mining injected more cash into the economy in the form of wages and increasing compensation payments. The large compensation payments began just as cash from Mount Kare was decreasing at the end of 1988.

In the construction stage, from mid 1989 to 1991, tension between the landowners and the PJV was increased by the insensitivities and carelessness of the 'fast tracking' construction contractors who were rearranging the Porgera geography. No amount of education or familiarisation trips to other mines can really prepare people for the impact of the loss of use (or permanent loss of land), for the impact of a large work force, and the indecent haste of construction. This was a period of maximum social disruption. Anger was directed towards the mine by people who either received no benefits or benefits below the level of expectation. Mining activity injected a great deal of cash into the local economy in the form of wages, business contracts, and compensation payments, while income from Mount Kare largely ceased. Categories of 'haves' and 'have-nots' were created, leading to jealousy and greed.

The first phase of operations, which began in 1991, was a period of adjustment, adaptation and re-evaluation. Cash income from wages and compensation was still significant but already declining. Royalty payments began, but there were fewer business contracts after construction had been completed.

The second phase of operations, which showed signs of emerging in 1992, was characterised by the anger of the children of the first generation of landowners who felt cheated by the greed or ignorance of their parents. Cash availability was greatly reduced: wages and royalties were the major source of cash income, but business contracts continued to diminish in value. The SML landowners were placed under additional stress by the problem of having so little time to adjust to the anger and frustration of their children.

\section{Urban development and physical infrastructure}

The Ipili of Porgera felt left out of the many changes taking place in Papua New Guinea. The mine represented the chance to catch up and 
enter the modern world. This led Porgerans to focus their energies on demands for physical infrastructure and economic gains. Anger and frustration continued to boil to the surface as limitations of finance and institutional capacity failed to cope with the seemingly endless list of demands for buildings on and near the government station and permanently closed Porgera airstrip.

\section{Towns and urban services}

The Porgera government station was established in 1961 by a land purchase from the Maipangi clan. The amount of land purchased, while adequate for the time, was not adequate for all the services and facilities needed for a town to service a large mine. From late 1989 to April 1991, Porgera Station experienced a building boom: several new residences, a guest house (Mountain Lodge), a police station with cells, a community centre, a women's resource centre, an office complex for the PDA, plus improvements to the health centre. There were also several improvements to the community school on land adjacent to the station but under a lease to the Lutheran church. In April 1991, there was a major landslide which lasted a couple of weeks. The slide destroyed the airstrip, the new police station and the women's centre, and threatened many other buildings before the ground stopped moving.

While growth had been substantial, there were still several amenities that Porgera Station did not have, even in 1993.

- Public toilets. Given the number of people who were congregating in the town on pay fortnights in an area with endemic typhoid, this was a major concern.

- Public telephones. The national government gave an undertaking in the Development forum that the Post and Telecommunications Corporation would be directed to install public phones within six months of the signing of the forum agreements in May 1989. Phones anywhere in the Porgera area were problematic in 1989. Public telephones were installed in Suyan for the use of PJV residents in 1991. But the delay in installing public phones at Porgera Station angered landowners and public servants alike.

- Post Office. This was also promised under the Porgera forum agreements. A post office agency was acquired by Ipili 
Porgera Investments' (IPI's) Sullivan's Store (later known as Supa Store) but since it operated out of Wabag it did not work. The PJV took out a box, and even altered its new address on stationary and business cards, but since the postal agency was inefficient the company ceased using it. In May 1993, public servants in Porgera still had to drive to Wabag to pick up mail-another source of frustration for themselves and local landowners.

With the subsequent development of Paiam township, it was assumed that a post office with public telephones would be constructed there, but there would still be a need for public toilets at Porgera Station.

In 1989, Westpac operated limited banking services from a container located in the yard of Sullivan's store. Bank agents did not always arrive for their scheduled fortnightly visits, which were meant to coincide with both PJV and government paydays. At that time, the government cash office also served as a Papua New Guinea Banking Corporation (PNGBC) agency which offered limited savings account transactions (for example with a maximum K200 withdrawal), but it was frequently unmanned. At a time when Porgerans had large amounts of cash from selling gold excavated at Mount Kare and from the large PJV compensation payments of 1989, the limited banking services did not support efforts to encourage savings. The armed hold-ups at the Westpac container certainly were a problem, but no more so than the armed hold-ups in other parts of the country. In 1990, the PNGBC opened a full branch in Porgera. Initially there was much chaos, as everyone who had Westpac accounts changed over to PNGBC, but this bank provided a much needed service. The bank manager was a popular guest speaker at women's leadership courses, and did a lot to encourage women to save their share of the compensation payments made for the Paiam land purchase.

As there was insufficient land at Porgera Station for urban growth relating to mine development, the national government purchased land at Paiam to cater for this need. The proposed services and facilities represented a new beginning, and even Porgera's entry into the 'modern world'. The development of Paiam Town was the responsibility of the PDA and the Enga Provincial Town Planning Board. Funding for public buildings came from various tied grants. The standard of commercial buildings was likely to be problematic. History has shown that most Engans and Porgerans do not invest in 
real estate in Enga Province because of the risk factor, so it was not clear in 1993 how successful the town would actually be. It promised to provide even more amenities (including a hospital, high school, and recreational facilities) to draw even more outsiders into the Porgera area. Some Porgeran leaders had an unrealistic picture of a peaceful, integrated town with no fences and a strict building code to ensure attractiveness. Yet one had only to look at the neighbouring towns of Laiagam, Tari, Kandep and Wabag to see the difficulties ahead: steel buildings with unsightly security fences; buildings burned and destroyed in payback or random violence; betel nut stains, graffiti and overflowing rubbish bins and litter.

Suyan, the other 'township' in the area, was really not a town at all-it was an accommodation compound for PJV employees. The land had not been purchased but had been leased by the PJV from the Aipakane clan. By mid 1993, Suyan consisted of six eight-room 'motels', 44 eight-room 'bunk houses', 30 three-bedroom married houses (of which 16 were actually occupied by families), a mess and an indoor sports complex. Many Porgerans were resentful that Suyan was a fenced enclave rather than an open, integrated town, but it was ironic that the very Porgeran leaders who wanted the fence removed from Suyan (and wanted no fences in Paiam town either) had fences around their own homesteads.

In 1993, the Porgera Local Government Council was operating a truck for rubbish collection in Porgera and Suyan, and was due to extend this service to the new Paiam township. Collecting rubbish is one thing-disposing of it is another. The problem of rubbish disposal was a mixture of the NIMBY ('not in my back yard') factor and the general instability of land in the Porgera Valley. Initially, the council was adding to the unsightly nature of Porgera Station by dumping rubbish into the Maiapam creek at the edge of the station.

Furthermore, the council was not providing a rural village service, and this meant that rubbish disposal was a growing problem in the relocation areas (see Chapter 4 ).

\section{Road construction}

The equation 'roads equal development' has a long tradition in PNG. Indeed roads do bring access to services and provide the means for marketing cash crops. Porgerans, like people of any other neglected area of Papua New Guinea, are keen for road development. There are two 
perspectives on road development in Porgera-one is the PJV's need for a lifeline to the coast, and the other is Porgerans' own desire for access.

The responsibility for the upgrading and maintenance of the Highlands Highway as far as Wabag has been the responsibility of the PJV. The road to Lae is the mine's very vulnerable lifeline. Indeed, if there had been no mine in Porgera, it is quite reasonable to assume that the Maip road would have collapsed, leaving the Porgerans without road access to Wabag, Mount Hagen and Lae. As popular as the upgrading of the Porgera-Wabag-Hagen road has been, the Porgerans have long wished for alternate access to Mount Hagen through Tari in order to ensure free access to Mount Hagen when clan tensions in the Laiagam District make road travel hazardous. While the road to Tari would provide an alternate route to Mount Hagen and Lae, the downside is that it would probably bring in more outsiders from the Southern Highlands and alcohol for the black markets which flourish in Porgera.

Road links to Paiela (under construction in 1993) are also a mixed bag of benefits and disadvantages. While many Paielans wanted easy access to Porgera and the benefits thought to derive from this access, some Paielans did not want the road. While it would possibly provide the means for some Paielans to live only part-time, as opposed to fulltime, in Porgera, and would open up potential for agricultural development (betelnut comes to mind), some Paielans rightly felt that they would pay too high a price in social disruption. On the other hand, the bridge and road access to Yuyan and Politika was und oubtedly popular, since the people of Yuyan felt slighted once their position as the commercial centre for gold-buying shifted to Mungalep and Alipis.

People, both landowners and outsiders, gravitate to roads. Nowhere was this more apparent than along the Tipinini-KairikPaiam-Suyan corridor. The same trend had also become a problem on the Waile Creek road. Yet the main problem with road development was the demand for instant construction. This was simply not feasible, and the outcome was that, in order to meet these demands, inadequate money was budgeted for road maintenance. The Yuyan road was barely trafficable in a four-wheel drive vehicle in May 1993. Another problem with the indecent haste of road construction is that machines tend to be used in situations where hand labour contracts could be issued. Hand labour may be slower, but it does spread the wealth. 
The most unusual feature of roads in and around Porgera was that some were literally paved with gold. Stockpiles of ore of too low a grade to be economically processed in Porgera were crushed and used to surface roads. Whenever this happened, people risked the danger of the dump trucks to try their luck mining the road.

Despite all the road-building activity, most local people still walked long distances, and often pedestrians were often overlooked in the demands for roads. Pity the pedestrian in Porgera. Heavy traffic made the roadside dangerous, as well unbelievably dusty when dry (two hours without rain would do), and muddy when wet. This dust and danger was a source of constant complaint from landowners and the Porgera Women's Association. The sealing of the road at Paiam town, and from Suyan to the mine site, made life easier for the pedestrian, and proposals had been made to construct pedestrian foot paths from Kairik to the minesite.

Both the PDA and PJV supported efforts to construct footbridges over rivers. Footbridges are a tremendous advantage for dangerous creeks and rivers, although they were not always utilised. One day, at the footbridge at the end of the Suyan relocation road, I watched in apprehension as a woman with bilum and baby on her back led her other children across the river. She was only about 100 metres from the footbridge. People do not change habits easily.

\section{Commuter mining}

Porgerans wanted a residential mining town to be built as one of the conditions for their approval of the mine. This requirement is contained in the Porgera forum agreements, as well as the Mining Development Contract between the State of Papua New Guinea and the PJV. Under the Mining Development Contract, the PJV is required to actively promote the residence of mine operations personnel in the Porgera area.

In 1993, most PJV employees were still working a shift of 20 days on and ten days off, commuting to and from their place of recruitment by plane or road. This arrangement is normally called commuter mining, but tends to be known in PNG as 'fly-in/fly-out' (FIFO) because of the fact that most employees commute by plane or helicopter. The FIFO issue has been a longstanding grievance of the Porgeran landowners.

The PJV constructed Kairik airstrip as required under the mining agreements. Opening of the airstrip was delayed due to arguments over the standard of the airstrip-both basic construction standards 
and the question of how the design limited the category of aircraft which could use the strip. Another source of grievance concerned terminal facilities. It was left to the PDA, the managers of the airstrip, to develop facilities for regular passenger services. The PJV constructed a terminal for its own employees who departed daily on charter flights. At this facility, everyone had to suffer the indignity of being searched for alcohol on the way in and gold on the way out.

Table 2.1 shows that the PJV had 720 non-Porgeran staff in 1993, and another 376 non-Porgeran award employees. It is not known how many of these employees were married. By May 1993, the PJV had constructed 30 married houses at Suyan, of which 15 were occupied by the 2 per cent of staff employees who were residing permanently in Porgera with their families. The remaining non-Porgeran work force was commuting by plane or road. ${ }^{2}$

The primary reason that Porgeran landowners wanted employees to reside in a town in Porgera was so that they could profit from business spin-offs. A second reason, though not often heard, was that, if most PJV employees and their families lived in Porgera, this would demonstrate a commitment by the PJV to remain for a 'long time'. The PJV's preference has obviously been for commuter mining. I say 'obviously' because the company could have made more efforts to comply with its commitments to urban development. While much of the PJV's cautious approach could be attributed to economics, the company had some other very valid reasons.

- The primary reason was the law and order situation. The PJV could not guarantee the safety of its employees. To add families would have made the situation even more difficult.

- Many non-citizen and coastal employees would not be willing to move their families to Porgera because of the law and order problem and lack of amenities.

- Another factor was the availability of land at Suyan and Paiam. Full compliance would have required further land acquisition, which might not have been in the best long-term interests of landowners.

There also appeared to be a lack of commitment by the national government to ensure that the PJV (in which it had a 25 per cent stake) actively promoted the residence of mine staff in the area. In one of his 1992 reports on the implementation of the Porgera forum agreements, the Porgera District Manager, Graham Taylor, wrote that the national government 


\section{Table 2.1}

\section{Category}

Staff

Trainees

Total
PJV employees by category and place of origin, March 1993

Origin

Number

Porgeran

20

Other Engan

78

Other Papua New Guinean

224

Non-citizen

418

364

189

187

125

41

20

1,666

Source: PJV records.

has not written to the Board of Management of the PJV outlining its requirements in this matter. Whilst we recognise that the PJV is taking steps to locate its staff in Porgera despite the constraints that exist, the onus in this matter is one for the National Government to spell out to the PJV what basic facilities the Government will bring to Porgera, what it will do to bring serenity to the place (and this must include reducing the migration in of squatters) and what timetable, what standard of houses it expects the PJV to put up. The National Government can not ensure the promotion of residence of mine personnel without giving a direction to the PJV and allowing the PJV to respond to the policy and the landowners to respond. This matter is unclear.

Members of the Porgera Landowners Association expressed concern in quarterly review meetings that the delays might lead to nonimplementation; and they were right.

\section{Health}

The difficulty in obtaining health data was extremely frustrating. I was initially denied access to information in Wabag. By the time this difficulty was overcome, the information had been destroyed when the provincial government office complex was burned to the ground in early 1993. Despite the fact that health staff in Porgera were very cooperative, reports on file were patchy. I was unable to locate any annual reports for Porgera District for the years 1987, 1988 and 1990, and for some reason, at the last minute, was denied access to 
maternal and child health data. Maternal and child health information was not included in the Porgera District Annual Reports for 1989, 1991 and 1992. By 1993, record keeping at the Porgera Health Centre had greatly improved due to the efforts of the new medical officer, Dr Padraig Kramer. A computerised system had also been introduced by Dr Michael Hohnen at the Anawe Medical Centre.

Besides the absence of health data, another problem in examining the health situation in Porgera was the lack of recent and reliable census information. With the unknown number of outsiders moving into Porgera, population projections previously used were meaningless. No one knew how many people were living in Porgera Census Division, nor the sex and age breakdowns which would be necessary to analyse infant welfare clinic coverage, supervised births, family planning acceptors, disease frequency and so on. In hindsight, time would have been more profitably spent investigating the aid posts in Porgera instead of pursuing the fruitless paper chase.

Anecdotal evidence supports the impression that health services in Porgera deteriorated from 1987 to 1989. As a result of the Mount Kare gold rush, many of the staff of both the Porgera and Paiela health centres and the aid posts left to try their luck on the gold fields. Health services in Paiela were reportedly the hardest hit. In addition, in early 1989, tribal fighting and tensions between clans in the Laiagam and Porgera districts led to frequent closures of the Porgera Health Centre because most of the health staff were nonPorgeran Engans. A further problem was shortage of drugs, which was (and still is) a nation-wide problem. From mid 1989, as a direct result of mining development, the health services in Porgera began to improve. The first improvement was long overdue maintenance on the health centre undertaken by the PJV's construction contractors. In mid 1989, the PJV's medical officer, Dr Michael Hohnen, arrived. In order to strengthen rather than compete with the government health services, he conducted clinics at the health centre and provided much needed medicine. His presence undoubtedly prevented many deaths during the 1989-90 typhoid outbreak as well as the continuing problem of infant pneumonia. This arrangement remained in place until the government medical officer, Dr Padraig Kramer, assumed duties in Porgera in 1991, thus fulfilling another of the long-awaited provisions of the 1989 forum 
agreements between the government and the landowning community.

\section{Health facilities and staffing}

According to the 1992 Annual Report, the Porgera Health Centre had 40 beds and a staff of 23 headed by a medical officer. There was no classification of staff by qualifications-for example Health Extension Officer, Nursing Officer and Community Health Worker. The 23 staff included six casual workers who I assumed to be the cook, cleaners and driver.

PJV's Anawe Medical Centre provided medical and occupational health services to PJV employees, contractors and subcontractorsapproximately 1,800 people altogether, including local Porgeran employees. The centre staff would also treat referrals from the Porgera Health Centre and would treat emergencies presenting at the mine site gate. The staff of the centre included two medical officers, three health extension officers, one anaesthetic technician/nurse/first aid trainer, one ambulance driver/first aid trainer, and three aid post orderlies / nurse aids. The centre was better equipped than the Porgera Health Centre and provided services to a much smaller population. Because the centre was not a government facility, it had the organisational capacity to hire and fire staff and to obtain the drugs and equipment needed to provide an effective service.

Construction on the new multi-million kina Paiam Hospital commenced in early 1994 . This facility was negotiated by Porgera landowners as part of the Porgera forum agreements. The desire for such a major facility was a reflection of Porgerans' desire for curative medicine when what was really required was more preventive medicine. While there was no question that Porgera health facilities needed improvement, there were good reasons to think that the plan for this hospital was inappropriate for local needs. The anticipated benefits of the new hospital were

- an improvement in diagnostic facilities which should prevent people from shopping around for 'cures' in Mount Hagen and Lae

- an improvement in operating facilities

- an improvement in labour wards and maternity facilities

- a possible improvement in staff morale (if improved housing were also provided); and

- the availability of dental treatment. 
On the other hand, criticisms of the proposed hospital included the following points

- it was a high-tech flashy solution which did not address the basic problems of health care

- it might attract even more outsiders to Porgera

- it would be difficult to keep clean

- it was not clear who would be running the hospital, and if the government were running it, that would be another problem

- given the general reputation of Enga Province and the prevailing attitude of some Porgerans towards the existing health staff, it would be difficult to recruit new outside staff for the hospital

- it would be costly to operate. ${ }^{3}$

The Porgera hospital thus showed every indication of becoming an administrative and financial nightmare. Another concern would then be the community response when the unrealistic expectations of the benefits of this hospital were not realised.

In 1987, aid posts servicing the Porgera Census Division were located at Politika, Yuyan, Mungalep, Tipinini, Pakoandaka, Kairik, Yapatep and Waruwari (mine) (Pacific Agribusiness 1987). In 1993, the aid posts were located at Politika (unmanned), Nekeyanga, Mungalep, Tipinini, Pakoandaka, Kairik, Yapatep, Kulapi and Yarik. The Waruwari aid post was moved to Yokolama \#2 in 1989, until the Anawe Medical Centre was completed on the plant site in 1990. As mentioned above, aid post services in the district were severely affected by the Mount Kare gold rush. There was a great deal of subsequent improvement and upgrading of aid posts and houses for aid post orderlies in all of Porgera District by the PDA under the PJV's Community Facilities Grant. In addition, as part of the relocation agreement, the PJV constructed aid posts and relocation houses for the government supplied staff at Yarik and Kulapi. The old aid post at Kairik, which was vandalised and virtually destroyed, was located on the site of the new airstrip.

\section{Disease patterns}

The leading causes of admissions to the Anawe Medical Centre were pneumonia, malaria, typhoid and trauma. The leading in-patient diagnoses at the Porgera Health Centre from May 1992 to February 1993 were pneumonia, diarrhoea/gastroenteritis, measles, typhoid 
fever, obstetric problems and anaemia (see Table 2.2). Typhoid was no longer as prevalent as it had been in the recent past. Dr Michael Hohnen (pers. comm.) reported that in 1989/90, 40 per cent of

\section{Table 2.2 In-patient diagnoses at Porgera Health Centre, May 1992 to February 1993}

Diagnosis

Pneumonia

Diarrhoea/gastroenteritis

Measles

Typhoid fever

Obstetric problems

Anaemia

Oral candidiasis (thrush)

Influenza/URTI

Heart problems

Assault injury

Open wounds

Dysentery

Eye problems

Chronic obstr. airways disease

Skin problems

Perinatal problems

Pelvic inflammatory disease

Ear problems

Musculoskeletal problems

Internal injuries

Fractures

Scabies

Psychiatric problems

Meningitis

Malaria

Accidental injury

Miscellaneous bacterial diseases

Motor vehicle accident

Abortion

Cancer

Miscellaneous viral diseases

Leprosy

Tuberculosis

Other

Total

\begin{tabular}{|c|c|c|}
\hline ICD Code & Frequency & Percentage \\
\hline 321 & 287 & 21.78 \\
\hline 016.1 & 149 & 11.31 \\
\hline 042 & 109 & 8.27 \\
\hline 011 & 80 & 6.07 \\
\hline 39 to 41 & 71 & 5.39 \\
\hline 200 & 62 & 4.70 \\
\hline$?$ & 45 & 3.41 \\
\hline 312 & 35 & 2.66 \\
\hline 25,283 & 31 & 2.35 \\
\hline E 551 & 30 & 2.28 \\
\hline 50 & 29 & 2.20 \\
\hline 016.2 & 26 & 1.97 \\
\hline 23 & 20 & 1.52 \\
\hline 323 & 20 & 1.52 \\
\hline 42 & 17 & 1.29 \\
\hline 45 & 17 & 1.29 \\
\hline 372 & 16 & 1.21 \\
\hline 24 & 15 & 1.14 \\
\hline 43 & 15 & 1.14 \\
\hline 49 & 15 & 1.14 \\
\hline 47 & 14 & 1.06 \\
\hline 079.1 & 11 & 0.83 \\
\hline 21 & 8 & 0.61 \\
\hline 220 & 8 & 0.61 \\
\hline 052 & 6 & 0.46 \\
\hline E 52 & 6 & 0.46 \\
\hline 03 & 6 & 0.46 \\
\hline E 474 & 3 & 0.23 \\
\hline 380 & 2 & 0.15 \\
\hline 08 to 14 & 2 & 0.15 \\
\hline 110 & 1 & 0.08 \\
\hline 032 & 1 & 0.08 \\
\hline \multirow[t]{3}{*}{02} & 0 & 0.00 \\
\hline & 161 & 12.22 \\
\hline & 1,318 & 100.00 \\
\hline
\end{tabular}

Source: Dr P. Kramer. 
patients spending the night at health centres were being treated for typhoid.

The main diagnoses among out-patients at Anawe Medical Centre were respiratory diseases, diarrhoea and influenza. As was the case with Porgera Health Centre, domestic violence-related injuries were common, but were not separately recorded. The Porgera Health Centre's 1992 Annual Report recorded 29,617 treatments at the out-patient clinic. Dr Kramer indicated that outpatient data, including diagnoses, was unreliable for a variety of reasons, but that the main out-patient diagnoses would have been respiratory diseases, cuts and sores, diarrhoea and other gastrointestinal diseases, and that injuries from domestic violence were common. It may also be noted that there were eight cases diagnosed as psychiatric problems during this period. While not viewed as a major problem, this diagnosis was probably on the increase due to the demands of the church, alcohol, marijuana, and stress in a rapidly changing society.

From May 1992 to February 1993, there were 23 in-patient deaths at Porgera Health Centre, the causes of which are shown in Table 2.3. ${ }^{4}$ It can be seen that pneumonia was the main cause of childhood admission and death. Children who died in hospital usually had a poor nutritional status and poor immunisation record, and tended to present late. Of a total of 354 under-five admissions, 19 (5.4 per cent) died after an average admission duration of 2.7 days. Of these deaths, eight ( 42.1 per cent) died within 48 hours of admission, before any effect from antibiotics could be expected.

The general trends in the pattern of disease may be summarised as follows

- scabies had declined due to improved water supply in relocation houses

- childhood pneumonia was still a serious problem

- typhoid, although endemic, had stabilised

- asthma was increasing along with the abuse of ventilators

- dental problems, especially in children, were on the increase due to the junk food syndrome

- new clustered living patterns and increased personal mobility were causing the spread of communicable disease such as measles

- domestic violence injuries were frequent, fracture of the ulna being the most common. 
Table 2.3

Age group

Perinatal

Neonatal

Infant

Toddler

School-age

Adult

Total
Causes of death at Porgera Health Centre, May 1992 to February 1993

Cause of death

Number

Asphyxia

Neonatal sepsis

Pneumonia

Measles

Septicaemia

Pneumonia

Gastroenteritis

n.a.

Typhoid fever

Cerebral malaria

Chronic obstr. Airways

Lung cancer
2

1

10

2

1

1

1

0

2

1

1

1

23

Source: Dr P. Kramer.

\section{Maternal and child health services}

In 1987, infant welfare clinics were conducted at Yapatep, Alipis, Suyan, Porgera Station, Waratore/Apalaka, Inginene/Politika, Palipaka/Paiam, Pakoandaka, Tipinini, Yuyane, Kairik, Anawe, Kakandaka, Mungalep (Pacific Agribusiness 1987). In 1993, clinics were conducted at Yapatep, Suyan, Porgera Station, Apalaka, Palipaka, Paiam, Pakoandaka, Tipinini, Yuyan, Kairik, Anawe, Kakandaka, Mungalep, Panandaka, Yarik, Kulapi. The 1993 clinic locations reflected changed settlement patterns. For example, Alipis village no longer existed, but there was a higher density of people in the Panandaka area. Kulapi and Yarik were newly created relocation villages.

The main activities undertaken in the monthly village clinics were the immunisation and weighing of babies. Clinic schedules were followed more regularly after the provision of transport by the PDA. The clinic nurses reported no major problems except that mothers working at the mine were not bringing their babies to the clinic. No problems were reported with regard to the immunisation programme, which covered Triple Antigen, Sabin, Pigbel, BCG and Measles. The government was out of Hepatitis B vaccine, which is needed to prevent liver cancer, and which is normally given to infants to reduce 
the disease pool. Protein energy malnutrition amongst children has not been a major problem in Porgera, but there was probably some under-reporting in the clinics due to inaccurate weighing methodsfor example weighing an infant in a bilum and not subtracting the weight of the bilum. Anecdotal evidence suggested there might be an increasing problem of malnutrition due to parents feeding infants and toddlers chocolate milk and lolly water. Junk food was certainly contributing to an increase in dental problems in young children.

As there was no qualified midwife, antenatal clinics were only conducted at the Porgera Health Centre. A cultural constraint to an antenatal programme in Porgera was women's shame to admit they were pregnant during the first trimester. Although there were 193 supervised births recorded at the health centre in 1992, it is not known how many unsupervised births there were in this period. Complaints about the conditions for giving birth at the health centre were often brought up at meetings of the Porgera Women's Association. Women did not want men to attend them during childbirth, and some (not all) of the staff treated the women in labour with contempt. These were justifiable concerns that could have been solved by the recruitment of a competent and caring midwife.

No data were available on the number of family planning acceptors. Staff at the family planning clinic appeared to be competent in their job and had the standard range of family planning methods available. Most women in the community appeared knowledgeable with regard to the benefits and methods of family planning, with Depo Provera being a popular option. Family planning services were not offered to single women or to married women without the consent of their husbands. This was not an outdated moral response, but a very pragmatic decision based on fear of payback from husbands or fathers. A common complaint from women was that they were tired of always being pregnant. Women lost control over their reproduction with the breakdown of the post-partum sex taboo. In Porgera there are no known traditional methods of contraception or abortion other than magic spells.

\section{Sexually transmitted diseases}

According to the SEIS, there were 18 recorded cases of sexually transmitted diseases (STDs) at the Porgera Health Centre in 1986, and 26 for the first quarter of 1987. It was felt that the low incidence was due to people travelling to Wabag or Mount Hagen for treatment. It was also predicted in the SEIS that there would be a considerable 
increase 'with the influx of a transient population of predominantly single males'. However, it is arguable that the subsequent increase in STDs was attributable to the Mount Kare gold rush. There was a rich storehouse of anecdotal evidence concerning the prostitution at Mount Kare, as well as the excesses of the successful Porgeran miners on their trips to Mount Hagen, Port Moresby, Australia and the Philippines.

Porgera Health Centre records indicate that 531 STD cases were treated in 1989, 201 in 1990, 520 in 1991, and 523 in 1992. The unusually low figure in 1990 was attributed to the loss of relevant records. The records contained no breakdown by sex or by disease (gonorrhoea, syphilis and donovanosis). The STD figures from the Anawe Medical Centre show a marked increase in 1992, from a reported 4-6 per month in 1991 to a total of 523 for 1992 (which is coincidentally the same number recorded by the Porgera Health Centre in the same year). The 1992 total was divided between 422 cases of gonorrhoea, 88 of syphilis, and 13 others. The increase was attributed to non-Porgeran national employees on field break not being treated in their home areas because government health centres had run out of the standard treatment. There was a decrease again in 1993 , with a reported 173 cases up to 20 June (gonorrhoea 147, syphilis 25 , and others 1). This decrease was attributed to greater awareness as a result of the medical staff giving health lectures on STD/HIV, and to the increased purchase of condoms from the medical centre (Dr M. Hohnen, pers. comm.). Most of the diagnosis for STDs at both health centres was clinical, but deemed to be fairly accurate. The Anawe Medical Centre figures are probably more reliable than the Porgera Health Centre figures due to the latter's problems with recording-as well as some suspected 'back door' treatment.

By 1993, there were no known cases of HIV in Porgera, but testing was not being done at either health centre. All overseas staff working in PNG were required to undergo HIV testing in order to obtain work permits. Diagnosis of AIDS in a 'payback' society would be a problem, and this was an argument against routine testing for HIV. With the high STD rate and the two confirmed deaths from AIDS in Laiagam (Post Courier 22 January 1993), it is probable that the HIV virus was already present in the Porgera population. ${ }^{5}$ There was a lot of gossip in Porgera about confirmed AIDS cases and the need to build a special house for 'these AIDS people' in order to isolate them from the community. In 1993, the government's own STD/AIDS education effort was limited to those attending the STD clinic. 


\section{Health extension programmes}

Staff at the Anawe Medical Centre began a health education programme in 1992. The programme included monthly lectures to the PJV staff (including over 500 Porgerans) in 16 locations throughout the mine site, and the 'Health Corner' feature in the PJV's Ipili Wai Pii monthly magazine. Topics covered by mid 1993 included personal hygiene, typhoid, nutrition, smoking, heart disease, STDs and first aid. PJV's Social Development staff had also done some health extension work (primarily with women) during the relocation programme and through the Porgera Women's Association. This focused on scabies, infant and child feeding, STDs and family planning, and on hygiene to prevent typhoid. At the Porgera Health Centre, some health advice was being given during treatment at the STD clinic, and also to women who attended the maternal and child health services and family planning clinics, but there had otherwise been no community level health extension programme conducted between 1989 and mid 1993.

The 1991 Porgera District Annual Report mentioned the formation of a 'Health Committee', and the 1992 Report mentioned that it had been disbanded, but neither mentioned its function. It was suggested that this committee might be reformed under the Porgera Local Government Council as part of a larger exercise to revitalise that body. Local government councils do have the power to make and enforce health rules, which then gives a health committee some teeth. It was not difficult to think of a list of topics which might have been included in a community level health extension programme for the Porgera area, to be implemented by a Health Extension Officer with the assistance of other medical personnel and even the PJV's media unit. Existing networks for implementation of the programme included the local government councils, aid posts, infant welfare clinics, literacy schools, youth and women's associations and their member groups, churches and schools.

\section{Health care delivery problems}

The health care delivery problems existing in 1993 could be summarised as follows

- Government provision of drugs and equipment ranged from inadequate to non-existent (for example the lack of Hepatitis $B$ vaccine in the country). Porgera Health Centre obtained assistance from the Anawe Medical Centre with X-rays and 
oxygen. Due to efforts and finance from the PJV and PDA, drug shortage was no longer a problem. However, there were still problems with drug theft, the unnecessary use of antibiotics, and petty pilfering of equipment by staff and patients.

- Although there had been significant improvements with regard to maintenance of staff housing since 1989, staff housing was still inadequate.

- In-service training still needed to be improved.

- Medical staff of the Porgera Health Centre had been verbally and physically abused by members of the community. Working under constant threats and intimidation was one cause of low staff morale.

- Nearly 85 per cent of the staff at the Porgera Health Centre were non-Porgeran Engans who were traditional enemies of the Porgerans. Some of the staff were blatantly contemptuous of the Porgerans, whom they regarded as inferior. Although one could recognise a need to transfer these staff and seek a better staff mix, this was likely to be difficult because coastal people are reluctant to work in the highlands.

\section{Education}

As with health services, the development of the Porgera mine was the catalyst for a significant improvement in education services in Porgera District. Porgera's poor educational situation received further setbacks in 1988 as a result of the Mount Kare gold rush, when teachers and students left to try their luck on the gold fields. However, after 1991, there were dramatic improvements in education for the whole district

- an increase from four community schools in 1986 (Porgera, Yuyan, Paiela and Tokopa) to ten in 1993 (Porgera, Yuyan, Tipinini, Mungalep, Apalaka and Paiam in Porgera Census Division, and Tokopa, Paiela, Alumanka and Andita in Paiela Census Division)

- the opening of the Porgera Vocational Centre in 1991

- access to the College of Distance Education from 1991

- introduction of the Free Education Policy in 1993

- the opening of the Paiam Independent Primary School in 1993

- an increase in district enrolments from 443 in 1986 to 1,943 students in 1993 
- the planned 1994 opening of Porgera Technical High School at Paiam.

By 1994, Porgera District would have achieved the necessary mix of educational institutions to cater for most of the pre-tertiary education needs of its people: vernacular pre-schools, community schools, international standard primary school, technical high school, vocational centre and access to the College of Distance Education.

As with health, there was the difficulty of obtaining information, especially with regard to high school enrolments. The lack of census information was also a problem. Visits were made to all schools in the Porgera Census Division. As no visits were made to schools in Paiela, the following discussion deals only with Porgera Census Division.

\section{Vernacular pre-schools}

Vernacular pre-schools are commonly known by the Tok Pisin translation Tok Ples Pri Skul. The Enga Provincial Division of Education called its vernacular pre-school programme Wambao Enga Pii Sikulu (WEPS), which had been adapted to Wambao Ipili Pii Sikulu (WIPS) for Ipili vernacular pre-schools in Porgera District. The Enga Six Year Education plan regarded vernacular pre-schools as a component of the community school system, so WIPS in Porgera was seen to represent a contribution to the overall goal of universal primary education.

Promotion of vernacular pre-school education is based on the premise that children who first read and write in their own language achieve better results in primary education. The introduction of WIPS in Porgera was facilitated by the efforts of linguist Terry Borchard, who had studied and was fluent in the Ipili language, and supported by PJV funding. If there had been no linguist, then the introduction of WEPS would either have been delayed or would have been introduced using a dialect of the main Enga language (which did seem possible at one stage). If there had been no PJV, then there would have been no funds to produce the teaching materials.

The first school to introduce WIPS was Mungalep in 1991, followed by Apalaka in 1992 and Yuyan in 1993. Both Paiam and Tipinini were hoping to start WIPS in $1994 .{ }^{6}$ The main problem facing the expansion of WIPS education in Porgera Census Division was the problem of finding suitable teachers, though I understand this was not such a problem in Paiela. It seems that people who had the required maturity and educational background often preferred to seek out higher paying jobs at the mine. 


\section{Community schools}

Prior to 1989, there were four community schools in Porgera Census Division, all of which were church agency schools: the Lutherans had schools at Porgera and Yuyan, the Catholic Church had one at Tipinini, and the Seventh Day Adventist Church operated a school at Kairik from 1974 to 1978 . The Tipinini school was closed in 1984 due to low attendance (see Pacific Agribusiness 1987, Appendix E) but re-opened in 1989. The Yuyan school opened in 1974 or 1975, but closed down in 1988 due to tribal fighting and perhaps also the effects of the Mount Kare gold rush; it re-opened for two months in 1990 then closed again until the beginning of 1992. The next school to open in Porgera Census Division was the Catholic agency school at Mungalep in 1991, followed by the government schools at Apalaka in 1992 and Paiam in 1993. In 1993, Porgera Community School became the first school in the district to have a non-teaching headmaster.

Funding for classrooms and teachers' houses for the new schools, as well as for more facilities in the existing schools (for Paiela as well as Porgera), came from the PJV's K4 million Community Facilities Grant to the PDA. Funds for teachers' salaries come from the Enga Provincial Division of Education. The PDA became committed to a heavy annual works programme to provide classrooms and teachers' houses for the schools which needed to expand to Grade 6, and this meant that it needed to concentrate its resources on improving the existing schools rather than bow to public pressure to open new schools in Porgera District.

According to the SEIS, Porgera Community School had seven staff and 210 pupils (113 males, 97 females) in 1986, while Yuyan Community School had five staff and 141 pupils ( 89 males, 52 females). Table 2.4 shows the overall pattern of enrolments by school grade in the six community schools operating in Porgera Census Division in May 1993, with the numbers of teachers in each grade shown in brackets after the number of pupils.

The low number of students in Grade 6 at Porgera Community School can be attributed to the Mount Kare gold rush, since 1988 would have been the Grade 1 intake for that year. The overall increase in enrolments is attributed to the growth of new schools, the increasing number of people moving to Porgera, a growing awareness by parents of the value of education, and the introduction of the free education policy in 1993. However, while we can clearly see that there had been an increase in total enrolments in schools in Porgera Census 
Division from 351 in 1986 to 1480 in 1993, it was still not known what percentage of school-age children were attending school. A standard education indicator used to analyse community school enrolments is the gross enrolment rate, which is the percentage of children aged 7 to 12 enrolled in schools. Without reliable census figures, this indicator was impossible to calculate, and it was therefore impossible to assess Porgera's progress toward universal primary education.

Because there was a lot of talk that outsiders were taking up valuable space in the community schools, I asked headmasters to indicate what percentage of their students were local Porgerans. This question was complicated, especially in Tipinini, by the problem of defining what constitutes a local Porgeran, and was more difficult in those schools with no Porgeran teachers. The results were

- no outsiders in Apalaka, Mungalep or Yuyan community schools

- 31 per cent outsiders at Porgera Community School

- 16 per cent outsiders at Paiam Community School; and

- 4 per cent outsiders at Tipinini Community School. The high percentage of outsiders in Porgera Community School is not surprising since this school was catering for children of residents of Porgera Station, as well as residents in the nearby communities.

Table 2.4 also shows that the increase in the number of teachers had not kept pace with the increase in enrolments. The SEIS reported a teacher/pupil ratio in 1986 of 1:29, compared with the overall 1993 teacher/pupil ratio of 1:44. The Enga Six Year Education plan stated that Enga Province had an overall teacher/pupil ratio of 1:31, which was below the World Bank recommended maximum of 1:35. But most Porgera schools were in excess of the World Bank recommendation in 1993. Grade 1 ratios were particularly high, indicating that these classes were little more than child minding centres. The intake of too many Grade 1 pupils reflected an inability of Boards of Management to say no to parents, and the belief that Porgera would continue to have a high wastage rate between Grades 1 and 2. The introduction of free education undoubtedly contributed to the problem. When I queried the teachers at Yuyan about the ludicrous figure of one teacher for 96 pupils, the response was that it was not so bad, because only an average of 50 pupils attended each day! There was a definite quality of education problem here.

Of the 33 teachers for 1993 (including WIPS teachers), eight were women and 25 were men. Bearing in mind the problem in defining 
Table 2.4 Community school enrolments by grade in Porgera Census Division, 1993

\begin{tabular}{|c|c|c|c|c|c|c|c|c|}
\hline School & WIPS & Grd 1 & Grd 2 & Grd 3 & Grd 4 & Grd 5 & Grd 6 & Total \\
\hline Porgera & - & $198(3)$ & $148(3)$ & $152(3)$ & $101(3)$ & $91(2)$ & $29(1)$ & $719(15)$ \\
\hline Yuyan & $48(1)$ & $96(1)$ & $59(2)$ & $22(1)$ & - & 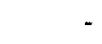 & - & $225(5)$ \\
\hline Tipinini & - & - & $84(2)$ & $=$ & $34(1)$ & $35(1)$ & - & $153(4)$ \\
\hline Mungalep & $31(1)$ & $34(1)$ & $63(2)$ & - & - & - & - & $128(4)$ \\
\hline Apalaka & $41(1)$ & $104(2)$ & - & - & - & - & $=$ & $145(3)$ \\
\hline Paiam & - & $110(2)$ & - & - & - & - & - & $110(2)$ \\
\hline Total & $120(3)$ & $542(9)$ & $364(9)$ & $174(4)$ & $135(4)$ & $126(3)$ & $29(1)$ & $1480(33)$ \\
\hline
\end{tabular}

Source: School records.

'what is a Porgeran', 27 of these teachers were non-Porgerans. The high percentage of non-Porgeran teachers meant that it was difficult to achieve the policy goal of having native speakers as Grade 1 teachers. Demand for more teacher housing could certainly have been eased if more local Porgerans became teachers. I do not know how many (if any) Porgerans were enrolled in teacher training colleges in 1993.

Table 2.5 shows the percentage of female pupils in each school grade in May 1993. The proportion of female enrolments shows a slight decline at Porgera Community School, from 46 per cent in 1986 to 42 per cent in 1993, and at Yuyan from 37 per cent to 32 per cent in the same period. But the Mungalep case shows a countervailing trend to equal or higher female enrolments. The overall 42 per cent female enrolment level compares well with the 1991 Enga provincial average of 39 per cent, but it could be argued that female enrolments needed to be improved at Yuyan and Apalaka.

Apart from the unacceptably high teacher-pupil ratios in some grades, and the lack of native speakers as Grade 1 teachers, the main problems with community schooling in Porgera in 1993 were

- Lack of curriculum materials-most schools visited had absolutely no textbooks or teachers' aids other than the WIPS reader printed by the PJV. The District Education Officer (who looked after the three districts of Porgera, Lagaip and Kandep) advised that this problem afflicted the whole province. This was particularly a problem for new schools which would, of course, have nothing left over from previous year's supplies when the system may have worked. 
- Lack of community support-This was listed as a major problem by teachers at all six schools visited. It appeared to be common for parents to pay a K20 fee to the school rather than show up for community work days. The PJV's Community Relations Section had assisted schools with library books, used computer paper (conspicuous in all schools), and minor maintenance and improvements such as water supplies to some schools.

- Vandalism and tribal fighting-Mungalep School had problems with vandals damaging classrooms, and there was also an attempt to burn the school down. Yuyan School suffered severe damage to classrooms and had to be virtually rebuilt. Destruction of schools as a result of law and order problems is a main constraint to extending education in Enga Province. There has always been the possibility of similar problems in Porgera.

- School lunches-teachers said that many parents did not provide their children with lunch. Some parents gave their children money which they spent on junk food or gambling. There were no school lunch programmes in any of the schools.

- Other-problems with subsidy cheques and teachers' pay as a result of the fire in the government offices at Wabag; lack of student desks; lack of sporting facilities; teachers' dissatisfaction with conditions and salary; and the school bus issue with Porgera Community School.

Table 2.5 Female community school enrolments by grade in Porgera Census Division, 1993

$\begin{array}{lcccccccc}\text { School } & \text { WIPS } & \text { Grd 1 } & \text { Grd 2 } & \text { Grd 3 } & \text { Grd 4 } & \text { Grd 5 } & \text { Grd 6 } & \text { Total } \\ \text { Porgera } & - & 51 & 50 & 34 & 45 & 42 & 45 & 45 \\ \text { Yuyan } & 48 & 39 & 15 & 14 & - & - & 32 & \\ \text { Tipinini } & - & - & 48 & - & 38 & 23 & - & 40 \\ \text { Mungalep } & 58 & 68 & 50 & - & - & - & - & 57 \\ \text { Apalaka } & 29 & 38 & - & - & - & - & - & 36 \\ \text { Paiam } & - & 47 & - & - & - & - & - & - \\ \text { Total } & 44 & 47 & 43 & 31 & 43 & 36 & 45 & 42\end{array}$

Source: School records. 
It was pointed out in the SEIS (Pacific Agribusiness 1987[2]:36) that the limited education base of the Ipili people was a constraint to their participation in the employment and business opportunities associated with the Porgera mine. The SEIS concluded that the main education need for Porgera was to improve the quantity and quality of students being prepared in the community school system for secondary and technical training. While the subsequent expansion of community school education (including WIPS) had been impressive, there was still a very definite quality-of-education problem in 1993, and there was still a need to find ways of inducing greater community participation.

In response to Kundapen Talyaga's 1979 study of educational problems in Enga Province (Runawery and Weeks 1980:5-6), the Enga Division of Education developed the Community-Based Education Policy. This policy stressed community involvement and participation. The PJV was part of the Porgera community and made significant contributions to community school education, especially in Porgera, but in other areas of Enga Province as well. Besides the Community Facilities Grant which enabled the building programme, other areas of PJV assistance included: library books, school prizes, celebrations, and assistance with school improvements such as minor maintenance needs and water supplies. But there was still a vast pool of human (as opposed to financial) resources in the mining community which could have been utilised to work with teachers and school boards of management to help improve the quality of education.

\section{Paiam Independent Primary School}

The construction of an international standard primary school by the PJV in Porgera was a condition set out in the Porgera forum agreements. Paiam Independent Primary School, which opened in 1993, was a dramatic contrast to the community schools in terms of facilities and resources. In 1993, there were three teachers for 28 students, and an impressive array of text books and teaching aids, including video and photocopying machines. This school was meant to be part of the community services which would encourage more families of expatriate mine workers to live in Porgera. However, better education is a goal of many Porgerans, and those who could afford it wanted to send their children to this school. In 1993, 13 of the 28 pupils were children of Porgeran landowners, and the proposed school expansion for 1994 was primarily to cater for the increased demand from local Porgerans. In this respect, the Independent 
Primary School promised to provide the foundation for an educated élite within the local community, and thus to create another division between the 'haves' and 'have-nots' in Porgera.

\section{High schools}

Most of the Porgeran students who have gone on to high school have attended Laiagam High School. As part of their overall development goals, Porgerans wanted a high school in their own district. The desire for a local high school is a common request throughout Papua New Guinea. Besides the obvious advantages (and prestige value) of having a local high school, Porgerans were concerned about the law and order problems that frequently affected their children attending Laiagam High School. In addition, many parents felt that the Engan teachers discriminated against Porgeran students.

Porgerans were successful in their negotiations to have a local high school in Porgera, in spite of the fact that they did not have the catchment level which is normally required for this purpose. According to the Enga Six Year Education Plan, Porgera Technical High School was due to open in 1994, with Grade 7 students from Porgera and possibly other nearby areas in Enga Province such as Mulitaka. The school would offer the standard national academic subjects together with two practical subjects-possibly mechanics and electricity. The plan also indicated that this school would gradually be blocked through to Grade 12.

I was unable to obtain any figures as to the number of Porgerans actually attending high school. It should have been possible to obtain these figures, as the PJV was providing financial assistance to Porgerans for high school education. Without figures for at least 1991, 1992 and 1993, it was not possible to assess if there was still a high wastage rate from Grades 7 to 10 , as previously reported in the SEIS. Another problem was the proportion of Porgeran and non-Porgeran children selected to go to high schools from Porgera and Tipinini community schools. At the end 1992, angry Porgeran parents claimed that the original selections were all outsiders, and the numbers from Porgera were subsequently increased. ${ }^{7}$

\section{Porgera Vocational Centre}

According to the Enga Six Year Education Plan (Ahai et al. 1991:90), three basic types of vocational centres have evolved in Enga 
- traditional vocational centres with a 'back to the village' focus

- specialised training centres; and

- mini or pseudo-high schools.

The Porgera Vocational Centre would be an example of a specialised training centre, since it focused on mechanics and carpentry, with limited formal classes in the curriculum of the national College of Distance Education (CODE).

Enrolments increased from 16 in 1991 to 30 in 1992, and 52 in May 1993. The centre was receiving technical support from the PJV, as well as financial support from both the PJV and the PDA. In support of the basic skills training, the centre made desks for the community schools and ran a vehicle repair workshop for minor repairs and service.

The Porgera Women's Association Resource Centre was rebuilt in the vocational centre compound after the 1991 earthquake. The plan was to build a larger women's resource centre at Paiam and hand this building over to the vocational centre for home economics training. The first female students were enrolled in the vocational centre in 1993, and with the female CODE teacher formed a small sub-group within the association.

\section{College of Distance Education}

As stipulated in the Porgera forum agreements, and in order to assist those Porgeran students who either were not selected to go to high school or who did not complete high school, the CODE opened a registered study centre in Porgera in 1991. Up to the end of 1993, the CODE centre shared the facilities at the vocational centre, but was due to move from this temporary home to a newly built centre in Paiam township. This centre was providing support services to students (including the vocational centre students) who were taking Grade 7 to 10 subjects by correspondence. The centre obtained financial assistance from both the PJV and the PDA. The number of students registered with the centre increased from 23 in 1992 to 102 in mid 1993, but 53 (51 per cent) of these 1993 students were non-Porgerans. The lower percentage of Porgerans could have meant that this school was catering primarily to the needs of outsiders, but it could have meant that Porgeran Grade 6 leavers were not interested in furthering their education, or that their numbers were insufficient to fill the places available. 


\section{Tertiary education}

The PJV had a scholarship programme which provided financial assistance to selected students undertaking tertiary studies. According to PJV records, three out of 30 sponsored students in 1992 were Porgerans, and only one Porgeran (out of a total 42) was being sponsored in 1993. As qualified Porgerans would have been given preference, this number indicates just how few Porgerans were undertaking tertiary studies.

\section{Literacy and non-formal education}

The provincial non-formal education function had moved from the Division of Education to the Division of Community Services and back to the Division of Education. Non-formal education focused on training programmes for youth and women and on adult literacy. In Porgera non-formal education programmes for youth and women have been undertaken through the district's youth and women's associations. The PJV Community Affairs Division has employed staff specifically to assist with these programmes. Porgeran churches have also been involved in youth training programmes.

Adult literacy has been a provincial priority, since 'over 90 per cent of the population of Enga cannot read or write' (Ahai et al. 1991:104). In 1991, the Adult Literacy Programme coordinated by the Porgera Women's Association began. In addition to course fees, the PJV and PDA also allocated funds to operate the programme. Besides administrative difficulties, the main problems encountered were the lack of teachers, arguments over which language to use ${ }^{8}$ and access to buildings in which to conduct the courses. There was a need for a full time Adult Literacy Coordinator responsible to the women's association, but the difficulty of obtaining a suitably experienced Porgeran for the position suggested that it might be necessary to recruit an overseas volunteer with a Porgeran counterpart.

\section{Women, marriage and the family}

The argument here is that women are the key element to family stability, especially during periods of rapid social change. Mine development had negative impacts on the lives of local women, but paradoxically also had the potential to provide opportunities for women to gain more control of their lives and influence the course of social change. Although the United Nations proclaimed 1994 as the 
International Year of the Family, the discussion in this section suggests that the family in Porgera had some serious problems in that year.

The time which Porgeran women were spending on domestic duties associated with their roles of mother, wife, food producer and tender of pigs was relatively unchanged. Meanwhile, outside influences (the steel axe, bisnis, education) had a significant impact on men's traditional roles. Porgeran women were therefore raising concerns that men were opting out of their traditional duties as they explored their own avenues to find the road to success. These traditional duties included heavy clearing, fencing, digging drains, house building and repairs, and care and discipline of children, especially male children.

Concerns raised by Porgeran women at formal meetings of the Porgera Women's Association, as well as in informal discussions, focused on

- the problems associated with polygyny

- deserted wives

- domestic violence

- problems of alcohol abuse and black markets

- access to family planning methods

- the need for money in an ever-growing cash economy

- the breakdown in law and order (especially the increase in rape and police violence); and

- concern for the future of their children.

Many of these concerns were similar to those raised by women in other parts of Papua New Guinea.

\section{Women and subsistence}

Women's primary economic activities still focused on the subsistence sector of the economy, with a great deal of their time spent on tending food gardens and raising pigs-though pig raising was no longer an activity for women who had adopted the Seventh Day Adventist religion. In addition, those women who had rights in areas of alluvial mining activity, or whose husbands had such rights, were accomplished gold panners. Some women also operated trade stores or engaged in informal trading activities which included the sale of home-made scones, second-hand clothes, and surplus food crops.

Women's primary traditional responsibility was food production. Subsistence agriculture was still the economic basis of Ipili society. Gold may have been the Ipili's second garden, but food was still the 
first garden. Not everyone in Porgera was an alluvial miner, and even for those families who did regard gold as their 'cash crop', it was still secondary in importance to subsistence agriculture. Older women especially liked the security of having and working their food gardens. It was a known source of control for them in a changing society.

Whatever the goals for rural transformation are, it is essential not to lose sight of the importance of subsistence agriculture. Trade stores and cash crops do not substitute in either the short or long-term for the value of food gardens. The problems of subsistence agriculture in the SML area have already been discussed. If the man was a wage earner, he would not necessarily give his wife the cash she needed to purchase food. Provision of food for daily meals was still viewed as a woman's duty. It was not unusual for a woman to be hit by her husband if she failed to produce a meal for him.

My own observations of food gardens in Porgera, both within and outside the SML, indicated that there was plenty of scope for improvements to subsistence agriculture in terms of variety, yields and agricultural practices. The SEIS and Robinson (1988:58) acknowledged the need for a didimeri (female agricultural officer) to assist primarily with the anticipated food garden problems of relocated landowners. The death of the under-qualified didimeri who worked first for the government and later for the PJV's Women's Division left a gap which was still waiting to be filled in 1993.

\section{Women in employment}

Women liked cash and the sense of control that went with it. Many younger women preferred to buy store food rather than work in the garden. Many women of all ages in Porgera were seeking employment. These women had even copied their menfolk and joined together to demonstrate for employment. However, while women appeared to enjoy the prospect of escaping the constant drudgery of child care and gardening, they faced similar problems to those of working women in the Western world. These problems included sexual harassment, male backlash, and child care arrangement problems.

In a predominantly male working environment, sexual harassment is almost inevitable, and was certainly reported by the PJV's female employees and those of their catering contractor, IPI-Poons. Laundry women working in bunk houses reported sexual harassment by male shift workers. There were also a few reported cases of sexual 
harassment of female employees, both national and expatriate, by male co-workers. Complaints of this sort were normally dealt with by the PJV's Welfare Officer or staff in the Women's Section. The male backlash for working women came from their husbands and from other male employees. For example, as a consequence of a domestic dispute, a husband might request that his wife's employment be terminated. There were also cases in which rumours were started that female laundry workers would be replaced by men.

Child care is a particular problem for working women everywhere. This has been especially true in Porgera and other areas of Papua New Guinea, where breast-feeding for one to three years is the norm. Older children can usually be taken care of at home under traditional arrangements, but babies who are being breast-fed need to be near their mothers. The centrally placed PJV creche was not successful, because the working environment was so widely dispersed, and this created difficulties of access by the mothers. The Social Development Officer dealt with problems on a case-by-case basis. The most serious problems were with the PJV's catering contractor, IPI-Poons, which employed the largest number of local women. Women feared that they would lose their jobs if they took too much time off to feed their babies. Another problem for working mothers was that of time lost when a child was sick. Going to the health centre at the government station virtually became a full-day chore. The clinic sister also reported that mothers working at the mine were not bringing their babies to the infant welfare clinics. These problems were not as serious for women employed by the government, because these women were nearer to their homes, and their failure to appear at work was not taken so seriously because public servants were seldom penalised for absenteeism.

\section{Losing control}

The breakdown of the custom requiring women to seclude themselves from men while menstruating brought women greater freedom. But the breakdown of the post-partum sex taboo brought them greater hardship. Women did not like to have children one after the other. This added to their workload. It was hard to do garden work and look after more than one child at the same time. Porgeran women appeared to be well aware of the advantages of family planning and the availability of contraceptives, but complained that access was denied by their husbands. The women in charge of family planning services at the 
government station would not give women contraceptives without the husbands' consent due to fears of payback. Men did not want their wives to have contraceptives because they feared that they might be promiscuous, and because men gained prestige from fathering lots of children.

Traditionally, women's influence was in the private realm, while men exerted their influence in public. This system may have been appropriate in the past because by remaining in private affairs and exerting indirect influence on public matters, women were sheltered from the risks of public life and left to concentrate on their primary goals-bringing up their children in safety and providing subsistence and wealth to their families' (Kyakas and Wiessner 1992:178). However, modernisation produced changes which women were unable to influence because they had no public voice. The new political, legal and economic institutions were all dominated by men. The need for women to have a public voice to influence change was the rationale behind the Porgera Women's Association. Women's associations have the potential to provide the support for women to take risks and enter the public debate. If women lose control of everyday events in their lives, not only are they further disadvantaged, but the future of the family is at risk.

\section{Domestic violence}

The subject of domestic violence as a national problem is well documented in a series of studies undertaken by the PNG Law Reform Commission (see Toft and Bonnell 1985). The stress created by rapid social change due to the development of the mine had probably increased the rate and severity of domestic violence in Porgera. This was due to men's anxiety over their own ability to cope with rapid change, women's anger over men taking new wives, and the problems related to relocation houses in polygynous marriages (see Chapter 4). While wives did hit their husbands, wife-beating was a bigger problem because it was more common and more severe. The doctors at both the government and PJV health centres reported their own concern about the number and severity of wife-beating cases. Rarely did battered men need treatment.

Women were not against domestic violence if a wife failed in her obligations-provided the beating was not too severe. When women felt aggrieved, they would provoke their husbands into hitting them. Either this would clear the air or the woman would then appear in 
public (enhancing the damage by not washing or tidying up in any way) to testify against unfair treatment. In marriages that were working, the husband would feel shame and compensate his wife. Women were especially concerned with alcohol-related domestic violence, as this was unpredictable and usually more severe, and they were also concerned about husbands who beat their wives in order to make them run away and thus avoid the obligation to repay brideprice.

Fighting between co-wives was common. In an extreme case, in 1992, a young Porgeran woman, who had recently become a third wife, was murdered by the jealous second wife. Fighting was also common between a wife and a woman who was felt to be in an adulterous relationship with her husband, as adultery usually led to marriage between the adulterous partners. That women appeared more often to take action against a co-wife or other woman, rather than the husband, is a reflection of women's powerlessness in society. But the incidence of domestic and sexual violence also needs to be placed in the wider cultural context where 'bouts of violence... were not only frequent in husband-wife relations, but in virtually all categories of relationships in Enga regardless of sex, age and relationship' (Kyakas and Wiessner 1992:165).

\section{Raising children}

Children are highly valued in Ipili society, as in most of Papua New Guinea. I am not aware of any customary practice of infanticide nor any recent cases of infanticide which would be an indication of stress in society. It was anticipated in the SEIS that an increase in the numbers of illegitimate children would be a problematic consequence of mine development, but this issue was not raised by the Porgera Women's Association, nor did the PJV Welfare Officer report any cases. However, problems of this kind could yet be a matter of concern in view of the reported increase in promiscuity among the younger generation.

The care of young children is generally seen as the role of women, but men also have a role in childcare, especially in the discipline of older children, and boys in particular. At a women's association meeting in October 1992, women said that, with more husbands abandoning their wives, they were worried about the discipline of their children. The general impression was that a lot of young children were very badly behaved - the most obvious example being those 
very young children, mostly male, who threw rocks, used obscene language, and flashed penises. My observations over a three year period were that young children of both sexes were generally left to their own devices, and were not disciplined until an adult, usually male, could no longer tolerate their behaviour, when the discipline was often over-reactive. The freedom of boys continued into adolescence, while girls soon adopted the female roles of caring for younger children and working in the gardens.

Apart from the general pattern of socialisation, the more specific factors which could have led to discipline problems included the growth of family size (too many children too closely spaced), domestic violence, alcohol abuse, and the practice of bribing children to go to school, giving in to their temper tantrums, and buying them junk food. There is also an argument that lack of discipline could be attributed to the abandonment of male initiation rights. Male initiation rights were very important in the past as a means to instil discipline and teach men the rules and responsibilities related to adulthood. The bottom line is that undisciplined children grow into undisciplined adults.

\section{Inter-generational conflict}

Although conflict between generations is not uncommon anywhere, the problem was particularly evident in the mine impact area. Areas of conflict centred around leadership, ownership of relocation houses, and distribution of mine benefits.

- Leadership conflicts were already much in evidence when people had to decide who would be their nominated representatives on the original Landowners' Negotiating Committee, and this type of conflict resurfaced with the subsequent formation of the Kaiya Landowners' Negotiating Committee (see Chapter 6). The big question was how and when should leadership be transferred to the younger generation.

- A second major area of conflict was the relocation house (see Chapter 4). Adult children of relocated landowners were demanding that they should have their own relocation house. It is normal in many societies for children to expect to live as well as or better than their parents.

- A third area of conflict was cash benefits. The substantial once-only compensation payments went to the parents. The next generation wanted its cash benefits as well. The 
situation was not helped by the lack of clear decisions over the future allocation of benefits from the trust fund set up for the children of SML landowners.

At the same time, the conflict between generations was only one aspect of the overall youth problem affecting Porgera and the rest of Papua New Guinea as well.

It was the next generation of landowners (and there were many adults already) who felt that they were sold out by their parents and would therefore cause problems in the future. Add to this the lack of gardening land, unemployment, lack of discipline, and the presence of alcohol, guns and outsiders who have nothing to lose-and you had a recipe for disaster.

\section{The Children's Trust Fund}

Under the conditions of the Porgera forum agreements, 10 per cent of the total mining royalties were being paid to a trust fund for the children of the SML landowners. According to the Department of Mining and Petroleum, this fund had received $\mathrm{K} 1,315,730$ by the end of 1992. The whole amount had been placed in interest-bearing deposits; there had been no disbursements. As of May 1993, the following matters relating to the trust were outstanding

- the trust deed had not been signed by the Minister for Finance

- a manager for the trust had not yet been appointed

- the updated list of SML landowners' children (the beneficiaries) had not been completed

- no decision had been reached as to the form of benefits.

In May 1993, it was planned to complete updating the list of SML landowner children. The list would be published and circulated for appeals. After this, it would be up to landowners to register their children. What was not clear to me was whether the beneficiaries would also include the grandchildren of registered landowners. There were already a significant number of grandchildren in 1993.

The delay in deciding what benefits would be distributed under the trust fund was likely to compound the feelings of dissatisfaction amongst the adult children of landowners. The main benefit for which these children were agitating in 1993 was relocation-type houses. It had been suggested that the fund could be used to provide such housing for landowners' children, but if this were to be done, then the fund would soon be depleted. Another suggestion was that this fund 
could be used to provide international-level primary education for the landowners' children. This would be problematic as it would lead to another form of distinction between the 'haves' and 'have-nots' in Porgera society. In addition, many children could end up being excluded because of their age or scholastic ability. One thing was certain: when the time came to distribute the benefits, there would be disputes.

\section{Law and order}

The deteriorating law and order situation in Porgera was the main problem affecting the quality of life of Porgerans and the long-term viability of the mine. The 'law and order' problems in Porgera need to be seen in the national context (see Clifford, Morauta and Stuart 1984), but Enga Province as a whole has had a particularly bad reputation for lawlessness. Most of the inhabitants have been affected by tribal fighting. There have been pockets of anarchy such as the Tsak Valley. In 1991, the situation in Laiagam town became so bad that public servants abandoned it to mob rule.

In Porgera, when discussing the law and order situation, it is important to bear in mind the different perspectives of the state, the Porgeran community and the PJV.

- Most Porgerans, like most people in Papua New Guinea, are concerned with restoring harmony and patching up relations which have deteriorated, or else with being a winner in a situation of conflict. The emphasis is on restitution and compensation rather than punishment. There is also no distinction made between civil and criminal offences.

- The state is concerned with the rule of law through the formal police-court-corrections system. The state punishes those who have broken its own laws, but this may not necessarily satisfy the victim.

- The PJV wants to run its own business of mining gold with a minimum level of civil disruption and crime affecting its operations.

These perspectives can be and often are in conflict.

\section{The justice system}

In 1989, the local police detachment was housed in Panandaka. As this land was required for mine expansion, the police station moved temporarily to the government station, then to containers located at the Anawe boom gate. ${ }^{9}$ In 1990, a new police station was opened at 
the Porgera government station. However, this impressive concrete building was only briefly occupied before being totally destroyed by the 1991 landslide. Police then operated out of houses on the station until the new police station at Paiam was completed later in 1992, by which time another police station had been built at Suyan. ${ }^{10}$ Many records were lost in these moves.

The local police detachment was backed up by the mobile squad. During 1989 and 1990, the mobile squad was frequently present in Porgera, primarily to clean up criminal activity on the road between Porgera and the Western Highlands border. ${ }^{11}$ This squad also assisted in preventing a serious tribal fight from deteriorating into a blood bath. In 1989 and 1990, the mobile squad had a reputation, with both the PJV and the more law-abiding segments of the Porgera community, of being a tough but responsible organisation.

Because of the problems facing the police, the PJV assisted with accommodation, transport, fuel and overtime pay. While the PJV had the ability to call upon police-as did anyone-the PJV did not in any way direct the police. However, community perceptions were such that any excesses of police action were blamed on the PJV. For example, in June 1991 police went to Laiagam High School to retrieve a PJV vehicle which had been 'impounded' by teachers and students. Police-both local and mobile squad-met with community resistance, and in the ensuing fracas, the police shot several high school students. In retaliation, decking on the nearby bridge was removed, thus cutting the road access into and out of Porgera. For several days there was a stand-off between the community and the police, and the whole incident was blamed on the PJV.

When the state increased its equity stake in the Porgera mine from 10 per cent to 25 per cent in 1993, the Rapid Deployment Unit (RDU) was created to protect such large 'national investments'. When the RDU arrived in Porgera, they were housed at the PJV camp in Tipinini. The community now had three different police forces to contend with-not counting the PJV's own Security Department. The local police detachment was viewed as the most benign. The mobile squad was feared or cheered depending on what action was taking place. But the RDU appeared to have absolutely no support at all from the local community. The RDU came into further disrepute when one of the men allegedly shot a Suyan landowner, and this resulted in community retaliation against the Suyan residential camp. I would argue on the side of the community, although not necessarily for the 
same reasons, that three different police forces were unnecessary. The state should have put its resources into strengthening the local police and the mobile squad, which could be called upon whenever the situation got out of hand.

Papua New Guinea's court system consists of the National Court, which handles most civil cases and criminal cases, the district courts, which handle summary offences, the land courts, and the village courts. ${ }^{12}$ In Porgera there was no resident District Court Magistrate until late 1993. Some of the Provincial Affairs officers at the government station were gazetted magistrates. However, in spite of the backlog of cases which built up when the visiting magistrate failed to appear, they did not often use their powers. Once Porgera had its own district court and resident magistrate, the main priority became the improvement of the village court system. An efficient village court system should not only handle the bulk of community level disputes; it should be able to defuse situations before they become major problems, act as a force for discipline in the community, and hopefully help to prevent some tribal fights. In 1993, only the Suyan Village Court was reputed to be functioning in a satisfactory manner.

The main problems with the operation of village courts in Porgera, including Suyan Village Court, were

- lack of training for village court officials

- lack of supervision and inspection of court proceedings and decisions

- problems with financial accounting

- discrimination against women

- a preference for adjudication over mediation

- bureaucratic problems at provincial level which have obstructed the gazettal of new magistrates.

Although Village Courts are not a traditional method of dispute settlement, they were an accepted and well-used system in Porgera. Nevertheless, women were very vocal in their criticisms of victimisation in village court decisions. They did not want the courts abolished; they wanted them to respond to women's complaints. Women also demanded that female magistrates approved by the Porgera Women's Association be appointed to all village courts. This was agreed, and women were appointed, but their appointments, along with those of new male magistrates, were not gazetted because of problems at the provincial level (Porgera District Annual Report 1992). 
The SEIS (Pacific Agribusiness 1987[1]:18) recommended that the village court system be strengthened by appointing 'a strong and capable Provincial Village Court Officer with the mandate to hire and fire staff, implement an effective system of supervising and training, and ensure sound financial accounting and control procedures are followed'. The Acting Assistant District Manager reported in 1992 that there had been no permanent officer to coordinate the Enga Provincial Village Court Office, thus casting doubt on the feasibility of any further recommendation for institutional strengthening at the provincial level. However, the PJV was indicating its own willingness to assist in strengthening the Porgera village court system by providing a temporary officer to work with a District Village Court Inspector appointed by the Division of Enga. The local system could also have been strengthened by the appointment of a police liaison officer, a gazetted welfare officer, a nominee from the Porgera Local Government Council and a nominee of the Porgera Women's Association.

All rural lock-ups in Enga province had been closed by 1993. The nearest correctional institution was Baisu, just outside Mount Hagen. Since Porgera already had a resident magistrate, court house, police station and police cells in 1993, there was an argument in favour of constructing a rural lock-up (in Paiam) to house minor offenders serving short sentences, who could then be made to do community work.

\section{Tribal fighting}

Tribal or inter-group fighting can be viewed as both a law and order problem and a method of conflict resolution. Prior to European intrusion, inter-group fighting was common throughout the whole of Papua New Guinea. Today it is primarily a highlands practice. Tribal fighting was harshly repressed in coastal areas by an authoritarian colonial regime. By the time the highlands were brought under the Pax Australiana, a more enlightened form of colonial rule had emerged. This led to a dramatic reduction in tribal fighting during the 1950s and 1960s. With the approach of self-government and independence in the 1970s, however, tribal fighting re-emerged as the primary method of conflict resolution.

Meggitt (1957:32) reported that, in 1957, the Ipili of Porgera were involved in continuous inter-clan feuding, even though 'the many clan fights appear to by-pass the mining claims'. By contrast, Gibbs (1977:22) observed that 'one of the changes brought by the 
government most appreciated by the people is the cessation of fighting, enabling them now [i.e. 1974] to move about much more freely and without fear'.

By noting the presence or absence of inter-group fighting in each census division the Clifford Report made a rough estimate of the percentage of population affected by this phenomenon (Clifford, Morauta and Stuart 1984). On this criterion, 20 per cent of $P N G$ 's total population, but 89 per cent of the people in Enga Province, were affected by tribal fighting in the early 1980s. By this criterion, it can be said that 100 per cent of Porgera Census Division's population was affected by tribal fighting in each year from 1989 to 1993.

Tribal fighting was a constant source of social disruption in Porgera. It was disruptive to the community because it resulted in deaths, injuries, and destruction of property, and because it restricted freedom of movement. It was disruptive to the mine because fighting often took place on the road, or encroached into the company's residential areas. Employees then took time off work either to participate in the fights, protect families, or flee due to fears of payback. As clashes often occurred between Porgeran and other Engan clans, and most public servants and teachers were from other parts of the province, government services were consequently interrupted. In 1993, the PJV's Community Affairs Section created a position for an officer to monitor civil unrest in the community, and to liaise with the police and kiaps for intervention and mediation.

As tribal fighting was so pervasive, I felt this was an area worthy of investigation. Tribal fighting was supposed to be reported in the monthly 'Situation Reports' submitted by each district office, but no such reports had been filed in Porgera since 1985 due to lack of directives from Provincial Headquarters (Jeffrey Puge, pers. comm.). I therefore attempted to compile basic information on fights from 1988 to mid 1993 by asking people who had knowledge of these fightskiaps, lands and community relations officers for example. ${ }^{13}$

Porgeran tribal fights differ significantly from those in neighbouring Enga-speaking areas in that they are of shorter duration and involve comparatively little damage to property. This can be attributed to lack of manpower, because it takes a lot of warriors to create the devastation seen after Engan wars. Furthermore, the cognatic kinship system in Porgera would tend to dilute clan loyalties in fights (Pacific Agribusiness 1987[1]:18; Burton 1991:12). But the impact of outsiders on Porgeran fighting was evident in the Kairik 
fight of 1992-93. This was an intra-clan fight in which each group had Engan allies, and the result was a fight of lengthy duration and destruction. Alcohol and motor vehicle accidents were new triggers for fighting. In addition, the gun had finally arrived in Porgera. This was inevitable, as guns were so pervasive in tribal fighting in other areas of Enga (and the highlands in general). While I did observe 'a gun' in one fight in Panandaka in 1993, I do not know if anyone had already been injured or killed by one in a local clan fight.

Compensation was the normal way to achieve a reconciliation between the warring parties. Cash could lead to an inflation in compensation payments and groups could opt out of compensation by saying that it was against their religion (if they belonged to the Apostolic or Seventh Day Adventist churches); but the biggest problem was that the increase in the actual number of fights, combined with the introduction of 'the gun', may have meant that the number of deaths and injuries outstripped a group's capacity to pay. At a meeting with women of the Maip-Mulitaka Women's Association, the women complained that all their efforts were going to produce sweet potato to raise pigs for compensation payments.

\section{Crime}

One problem in analysing any trends in crime is the lack of any annual crime statistics for Porgera before 1992 (see Table 2.6). ${ }^{14}$ Even the 1992 figures may underestimate the number of cases reported to the police, as there was a reference in the Annual Report to a 'torn' Occurrence Book. There was also the usual problem of trying to determine how much crime was reported to the police. Police attributed the low arrest rate to victims preferring compensation.

The reported wilful murders do not include deaths in tribal fighting. The three murders recorded in 1992 were those of a young woman by a co-wife, the pack rape and murder of a young woman after a disco, and the murder of a man during compensation negotiations. I am unsure if the co-wife was convicted or still awaiting trial in 1993. There were no convictions for the other two murders.

As is true world-wide, it was difficult to document whether the incidence of rape was increasing or not. However, Porgeran women felt that it was increasing in Porgera. As the victim received no justice under the legal system, rape was often not reported to the police. Restitution was achieved by compensation and reputedly through the village court, even though this offence is outside this court's 
jurisdiction. Pack rape is a recent and unfortunately common practice in many parts of Papua New Guinea, not just the highlands. However, until the two vicious pack rapes of 1990 , this practice was not common in Porgera.

There were three types of arson committed in Porgera: police arson, arson in tribal fights, and payback arson. Most arson from 1989 to 1993 , in terms of the total number of houses burned, had been done by the police. In one case, the police burned and looted approximately 39 houses in the Mungalep area after the official opening of the Porgera mine on 20 October 1990. In late 1993, the police burned over 300 houses at Paiam in retaliation for the killing of a fellow policeman (Laurie Martin, pers. comm.). Arson was not a feature of tribal fighting until the Kairik fight in early 1993.

Incidents of theft ranged from armed robbery to minor thefts of anything that was left unattended for the briefest moment. The two largest robberies in Porgera were the 1990 armed robbery of the

Table 2.6 Porgera crime statistics, 1992

$\begin{array}{lcc}\text { Indictable offences } & \text { Reported } & \text { Arrests } \\ \text { Armed robbery } & 2 & 0 \\ \text { Wilful murder } & 3 & 4 \\ \text { Arson } & 4 & 0 \\ \text { Attempted robbery } & 3 & 0 \\ \text { Break and enter and stealing } & 9 & 0 \\ \text { Attempted murder } & 1 & 1 \\ \text { Rape } & 5 & 4 \\ \text { Carnal knowledge } & 2 & 2 \\ \text { Grievous bodily harm } & 4 & 4 \\ \text { Indecent assault } & 2 & 0 \\ \text { Wounding } & 6 & 3 \\ \text { Summary offences } & & \\ \text { Common assault } & 102 & 44 \\ \text { Stealing (minor) } & 49 & 21 \\ \text { Fighting } & 19 & 21 \\ \text { Tribal fighting } & 3 & 0 \\ \text { Drunk } & 1 & 1 \\ \text { Drunk \& disorderly } & 2 & 2 \\ \text { Threatening behaviour } & 28 & 3 \\ \text { Adultery } & 2 & 0 \\ \text { Escape } & 10 & 9\end{array}$

Source: Porgera District Annual Report, 1992. 
Westpac bank agency and the 1990 New Year's Day riot and looting of the IPI Supa Store. Armed robbery and hijacking of vehicles with goods for the PJV and Porgera stores was less common in 1992-93 than in 1989-90. However, the PJV, banks and stores were not the only victims of theft; it was pervasive in the community and was even common within families. Women carried the family bank passbooks in their bilums as it was not safe to leave them at home, and even then women often had these passbooks stolen. The 1992 figure of 49 reported 'minor' stealing offences indicates that most thefts were either unrecorded or unreported. Minor theft charges were also heard in the village courts.

\section{Riots, roadblocks and demonstrations}

This is another area in which it proved difficult to obtain information. As with tribal fighting, there were no Situation Reports which might mention major riots and demonstrations. The PJV's Community Affairs and Security section reports only mentioned those events which had or could have had an impact on mine operations. Incidents which might be noteworthy in more peaceful areas of the country (for example riotous behaviour at the Lands Office or minor roadblocks) were accepted as part of daily life in Porgera.

Mob action and violence was common at Porgera Station, especially on pay days. Roadblocks were another common method of airing grievances. Most roadblocks in Porgera were directed at the mine. This was frequently the case during the indecent haste of construction, when foreign contractors overstepped agreed land boundaries. Many grievances could have been sorted out first through discussion. While I witnessed some pretty scary mob action, all the roadblocks I encountered were relatively peaceful events. The object was to air a grievance, not to engage in combat, but this in no way condones what was usually an illegal action.

Examples of serious riots which took place in Porgera include

- the looting of IPI store on New Year's Day in 1991

- the riot stemming from the union strike at the mine in May 1991

- the attack on the mining camp at Suyan on the night of 14-15 October 1992.

The only surprising thing about this serious attack on Suyan was that it had not happened sooner. It was an event waiting for a trigger. In a place of known violence and with grievances against the mine, it was 
not strategically sound to house employees so far from the mine site. When trouble occurred, mine employees either stayed in camp or ran the gauntlet. Even with all the new security arrangements which now give Suyan the appearance and ambience of a prison, it would be hard to say that the risk of such an attack has been removed. ${ }^{15}$ There are plenty of Porgerans with grievances against the mine and vast numbers of idle outsiders ready to fuel these grievances or join in demonstrations. The rent-a-crowd mob have nothing to lose.

\section{Outsiders}

A squatter is a person who settles on land without authorisation. As most non-Porgerans residing in Porgera have had landowner permission to reside, it is more accurate to say that Porgera has had an 'outsider problem'. While there are no census data to indicate just how many outsiders were living in the Porgera Census Division during the period of this study, there was agreement by all (the Porgeran landowners, the provincial government officers in Porgera, and the PJV) that the numbers were considerable. It also appeared that most of the outsiders were western Ipili people from the Paiela Census Division, Enga-speaking people from the Maip-Mulitaka, Kera-Lagaip and Wage census divisions of Enga Province, and Huli people from the Tari Census Division of the Southern Highlands Province. People from all these areas had traditional links with the Ipili of Porgera. The Ipili granted permission to outsiders to reside for reasons of culture and commercial gain. Relatives and families of the person obtaining residence then moved in, and this led to a chain migration problem.

A distinction must be made between the more permanent outsiders who resided in Porgera and the considerable number of temporary outsiders who came to Porgera during the fortnightly pay day period, known locally as the 'thank you market'. Six provinces have highway access to Porgera: Morobe, Madang, Eastern Highlands, Simbu, Western Highlands and Southern Highlands. While the highway provided easy access to Porgera, it also meant that people could easily return to their homes. It is quite possible that Porgera would have had even more outsiders and a larger 'squatter problem' if there was no highway. A programme to reduce the number of outsiders in the Special Mining Lease was actually undertaken by the PJV in their capacity as the leaseholders. The two most positive features of this programme were landowner support and lack of violence. 
The permanent and temporary outsiders had different reasons for coming to Porgera. Many permanent outsiders came to Porgera for quality of life factors: employment possibilities, access to health and education facilities, and even to reside in a more peaceful place.

Temporary outsiders came for economic gains, which included selling goods at pay day markets, obtaining part of the wages of relatives or friends, and prostitution. Many came simply for the excitement, and these formed the bulk of the ever-ready rent-a-crowd that joined in the fights and riotous behaviour which became a standard feature of pay day. As previously mentioned, the social and environmental problems caused by excessive numbers included overcrowding, shortage of land for food gardens, lack of firewood, and pollution of creeks and rivers (see Chapter 5). As outsiders could return to their own land and communities, they had little to lose on their own account, but might gain by joining forces with Porgerans and encouraging them to take action over real or perceived grievances.

\section{Unemployment}

Unemployment has been a major issue in Porgera. It was the cause of an unknown number of demonstrations, mostly peaceful, some of which were staged by local women. The mine and its contractors were the major employers in Porgera. Employment preference was given to Porgerans but, due to the lack of education in the community, most employed Porgerans were in unskilled or semiskilled positions. Many Porgerans were resentful at the number of outsiders employed by the mine. However, given the education base at Porgera, it would be many years before there would be enough qualified and experienced Porgerans to occupy skilled and senior positions in the mine work force. There were very few wage employment opportunities in Porgera besides those offered by the PJV and its contractors. Some Porgerans were involved in alluvial mining and business activities, but most Porgeran-owned businesses were spin-offs from the mine (see Chapter 7). In 1993, there was virtually no agricultural base in the district other than a few small-scale coffee and vegetable growers, though the government had already set up an agricultural base camp at Tipinini for coffee and vegetable extension programmes.

All this pointed to large numbers of unemployed or underemployed people living in a valley which was very much geared towards the life-styles of a cash economy. Easy money from the Mount Kare gold rush, and from PJV and government land compensation, 
meant that people's expectations for a reasonable wage were definitely too high from 1988 to 1991 . Add grievances and mix with rent-acrowd, and you had a recipe for civil unrest.

\section{Alcohol and drug abuse}

Money made at Mount Kare led to an increase in alcohol-related problems in Porgera. In response to this, the Enga Provincial Government banned both the sale of alcohol and its importation into Porgera in late 1988, with the sole exception of the restricted club licence at the mining camp. In 1989, the escalating law and order problems in Enga Province led to a province-wide ban on the sale and importation of alcoholic beverages. ${ }^{16}$ While there were pressures to ban alcohol, there were pressures to remove the ban, once it was in place, due to loss of revenue by the provincial government and the inability of the police to control black markets. Alcohol black marketing was common in Porgera due to the wealth of the population. Large compensation payouts were generally followed by periods of alcoholic haze. There were also indications that the local black market was well organised.

Alcohol abuse was primarily a male problem in Porgera. The Porgera Women's Association, like its counterparts throughout Papua New Guinea, frequently had alcohol-related problems on its agenda. Women in Porgera knew the who, how and where of alcohol black marketing, but did not wish to report this information to the police for fear their houses would be burnt. ${ }^{17}$ The women's main concerns regarding alcohol abuse were the resulting incidents of domestic violence, loss of family income, motor vehicle accidents, and the numbers of children and adolescents who were learning to drink with their male relatives. While prohibition leads to black markets, the alcohol-related problems in Porgera would probably have been much worse if alcohol had been sold in legal outlets. In 1993, the Enga and Porgera women's associations both wanted the alcohol ban to remain in place throughout the province.

In 1993, there was only one recorded case of someone growing marijuana in Porgera, and this was ironically on the government agricultural station. However, marijuana was easy to obtain and was thought to be imported into Porgera along with the fortnightly influx of people on pay days. 


\section{Prostitution and promiscuity}

Obtaining any specific information on the subject of prostitution was a real problem. There were reports of two female prostitutes operating from an Alipis disco in 1987, as well as reports of prostitutes operating in the gold fields of Mount Kare. I heard many stories of Porgeran men spending Mount Kare and compensation money on the good life in Mount Hagen, Port Moresby, Cairns and the Philippines. There were also a few stories of Porgeran women soliciting in Mount Hagen. Prostitution in Porgera itself appeared to be primarily a problem caused by the pay day influx of outsiders. There were unconfirmed reports of prostitution being conducted out of one or two houses in Porgera government station.

Concerns expressed by women did not focus on prostitution per se, but on the incidence of adultery, the possibility of contracting AIDS from unfaithful husbands, and the increasingly promiscuous behaviour of young people. Adultery was a major issue with women because it usually led to marriage. My impression was that more men were committing adultery than women, and that the increase in adultery was correlated with the influx of wealth from Mount Kare and mine compensation payments. Adultery was not only socially disruptive because of its association with polygyny, but also because it led to domestic violence and an increased risk of sexually transmitted diseases. As we have seen, domestic violence was a serious social problem in its own right, and one that could not be easily overcome, given the overall level of violence in the community.

\section{Other socially disruptive factors}

Three other causes of social disruption may also be mentioned here: quarrels over land compensation, the incidence of gambling, and the conduct of local 'discos'. In order for construction of the mine to begin, the PJV needed to acquire land and compensate the owners for the temporary or permanent loss of land use and for improvements to the land-mainly food gardens, economic trees, and buildings. Investigations by PJV's lands officers resulted in disputes over land boundaries and the rights to receive the compensation-whether in the form of cash payments or relocation houses. This was a major source of social disruption in the SML in 1989, and in Suyan and Kairik in 1990. 
Unlike alcohol consumption, gambling was an activity widely practised by both sexes. High stake gambling was common after compensation payments. It was also common for children to gamble. The most common form of gambling was card games, although snooker and darts were also quite popular. ${ }^{18}$ The Porgera Women's Association expressed concern that some women were gambling to such an extent that they were neglecting their children. This appeared to be a new problem in Porgera, which was associated with the recent inflow of cash. My own observations of card games in Porgera indicated that there was less cash involved in 1993 than in 1989-90, though when I remarked on this, one woman pointed out that the players hid the paper money when I came around. The President of the Enga Women's Association, Scholla Warai, reported that many women living in Wabag town were spending a lot of time gambling, and consequently neglecting their children and household duties.

It was (and still is) common in many parts of Papua New Guinea for a community to raise funds by charging admission to dances held in a fenced-off area. In some parts of the country these dances to raise money have been called 'six to sixes' (i.e. dusk to dawn), but today the more common name is 'disco'. A major change in the conduct of discos in Porgera was that they were no longer supervised community fundraising events, but a form of private business where security arrangements were designed to protect the property of the owner, rather than to ensure communally acceptable forms of behaviour. As with alcohol, there was nothing inherently wrong with discos; it was the activities and behaviours associated with them that caused problems and community concern. Discos were as popular with young people in Porgera as they are world wide. The problems in Porgera were black market alcohol, marijuana, prostitution, and the fear that attendance would lead young people into promiscuous behaviour-not to mention the problem of noise pollution. A disco was blamed for the dreadful pack rape and murder of a young girl in October 1992. The problem was that in Porgera, with the increased number of outsiders and the general breakdown of family discipline, it was virtually impossible to obtain an acceptable level of supervision and security to ensure that discos were both fun and socially acceptable.

\section{Institutional strengthening}

In the period covered by this study, there had been a disproportionate amount of energy and resources directed towards works programmes 
in Porgera to the neglect of quality of life issues. This was understandable, as Porgera was one of the least developed districts in Enga Province. But once many of the infrastructure demands had been met, the time had come for institutions to direct their resources and energies to the following quality of life investments

- establishing peace and good order in the community-a fundamental prerequisite for social and economic development

- providing more education, formal, non-formal and informal

- improving the health status of the community by concentrating on preventive rather than curative measures

- improving income-earning opportunities for the majority and not the few, while ensuring that immediate economic gains would not be achieved at the expense of future generations

- improving the status of women so they could participate in, and benefit from, development.

\section{National and provincial government}

The national government's mineral revenues are supposed to be directed towards development in various social and economic sectors. However, as Jackson (1993:169) comments in his review of the Ok Tedi mining project

...the hope that mining would kickstart more desirable and appropriate forms of development around the country has clearly been disappointed. In the twenty years since BCL opened there are very few indications that general development levels in the country have shown anything more than sluggish, partial growth. Agricultural performance, admittedly in the face of almost continually declining world prices, has been particularly abysmal. Like almost all other developing countries heavily dependent on metal exports, the PNG government has not been able to utilise mining revenues to raise productivity elsewhere in the country.

This suggests that the national government is unlikely to have the political will or institutional capacity to assist Enga Province to maximise the benefits that can be obtained from having a world class, profitable mine within its boundaries.

The main financial benefits of the project to the Enga Provincial Government have been the royalties paid on mine production and a Special Support Grant from the national government. Royalties initially represented 1.25 per cent of the export value of the mine's 
output. ${ }^{19}$ These were paid by the PJV to the national Department of Mining and Petroleum, and the provincial government then received 77 per cent of the total, while the remaining 23 per cent went to: the SML landowners (8 per cent), the PDA's community development fund (5 per cent), and the 'Landowners' Children's Trust Account' (10 per cent). In addition, the national government has agreed to pay the provincial government a Special Support Grant which represents 1 per cent of the export value of the mine's output. According to the Porgera forum agreements, Special Support Grant expenditures are subject to national government approval and are supposed to be accountable on a quarterly basis.

According to the Department of Mining and Petroleum, the provincial government had received $\mathrm{K} 6,665,000$ from the Special Support Grant and $\mathrm{K} 10,154,229$ from mining royalties by the end of 1992. I was unable to find out how this K16 million had been used. ${ }^{20}$ This highlights three problems

- the lack of accountability for public monies

- institutional incapacity to design and implement infrastructure construction projects; and

- Engan attitudes to mine benefits.

Many angry Engan people were complaining that they had received no benefits from the PJV. This attitude was understandable. The provincial government's failure to direct the above K16 million to infrastructure projects in Laiagam, Kandep, Wabag, Wapenamanda and Kompiam districts placed the PJV in a difficult situation. In order for the PJV to secure road access through Enga province, Engans needed to perceive that they were receiving benefits from the PJV. The PJV's response was firstly to increase its public relations and community development assistance to areas outside Porgera District, and then to introduce the Resource Development Tax Credit Scheme (later known as the Infrastructure Tax Credit Scheme), as an arrangement between itself and the national government, under which it could deduct the cost of infrastructure construction projects up to the value of 0.75 per cent of gross income from its corporate tax liability.

Lack of accountability and corruption have been allegations frequently made of both the national government and various provincial governments. The main difference between the targets of these accusations is that the national government has had the power to suspend provincial governments. The Enga Provincial Government 
was suspended twice for financial mismanagement in the decade preceding this study. The problem with suspending provincial governments, and replacing the elected provincial politicians with a caretaker administrator, is that this rarely did anything to improve the performance of the provincial public service. The effectiveness of public servants in the Department of Enga did not improve, despite the efforts at institutional strengthening under the province's integrated rural development project, called Enga Yaaka Lasemana, which operated for most of the 1980s. ${ }^{21}$

Problems facing the Enga public service included

- lack of middle management skills to get things done, which was exacerbated by the problem of attracting skilled public servants to work in Enga

- tribal fighting, which not only prevented the delivery of services and destroyed infrastructure, but also became an excuse for public servants, especially extension staff, to fail to perform their duties

- buck-passing between the national and provincial government, the opportunities for which were further increased when functions were decentralised to the district level

- an excessive number of policies and policy changes

- regional divisions between eastern and western parts of the province; and

- poor staff morale.

Deficiencies in the public service were recognised, but the proposed remedies had not made much difference

- divisions were restructured, and functions decentralised to the district level, without the staff and resources required to make the system work ${ }^{22}$

- staff were reshuffled without the means or the will to get rid of 'dead wood'

- conferences, workshops and planning exercises became an end unto themselves.

The experience of integrated rural development projects in Enga and other provinces (East Sepik, Southern Highlands, Milne Bay) suggests that sustainable institutional strengthening was not achieved because these projects operated alongside of, instead of being integrated into, the provincial public service, and because expatriate contract officers were placed in line positions in order to achieve immediate results. 
The improving performance of the public service in Porgera itself (known as the Division of Porgera) was reflected in the Annual Reports. Had it not been for the presence of the mine, it is doubtful whether there would have been any improvements, and arguable that there might even have been a further decline. Most probably, the road connecting Porgera to Laiagam would have become untrafficable, leading to a further deterioration of services. While there had been significant improvements in health, education and agricultural extension staffing, other rural extension services were still almost nonexistent. Many of the significant improvements in Porgera could be credited to the efforts of the PDA rather than the provincial government. Nevertheless, Division of Porgera staff, with assistance from the PDA and the PJV, had the potential to strengthen other institutions to be models for the rest of Enga Province, specifically: the local government councils, the village court system, and government extension programmes.

\section{The Porgera Development Authority}

The PDA was formed in 1989 as a fourth level of government between the provincial government and the two local government councils in Porgera District. The PDA's general functions, as specified in its own legislation, were to

- control, manage and administer the Porgera District

- ensure the welfare of its residents

- assist the local government councils in carrying out functions within the district

- maintain the Kairik airstrip

- receive and distribute royalties from the provincial government

- administer the spending of monies under the PJV's Community Facilities Grant (K4 million by 1993)

- advise on liquor licensing matters in Porgera District; and

- assist the Provincial Town planning Board in planning any township in Porgera District.

The rationale for creating a fourth level of government was to overcome the bureaucratic constraints of local government legislation in order to get things done, and to ensure that both local government council areas received their due share of mine-related benefits. In the short term, the PDA was an effective institution for getting things done. The PDA demonstrated accountability for the money it 
received..$^{23}$ The PDA was responsible for the building and upgrading of community schools, aid posts, recreation facilities, minor roads and bridges, as well as the development of Paiam township. However, the formation of the PDA compounded the institutional weakness of both Porgera and Paiela-Hewa local government councils.

\section{The Porgera Local Government Council}

The development of provincial governments weakened the local government system. The focus of centralisation merely moved from Port Moresby to provincial capitals, while the quantity and quality of services to rural areas declined. By 1993, this outcome had been officially recognised by the national government with its launching of the Village Services Programme. Although this programme appeared to be specifically aimed at revitalising local or community government councils, it also seemed to make some provision for by-passing these bodies.

Following the creation of the PDA, the activities of the Porgera Local Government Council were mainly confined to the operation of garbage collection contracts at Porgera Station, Suyan and the mine site, the construction and maintenance of market facilities, and the cleaning of Porgera town. In addition, the council was receiving the village court fines and using this money to upgrade village court facilities. But local councils have the potential for engaging in a wider range of activities. The 1992 Porgera District Annual Report indicated that the Porgera council had an interest in both law and order and public health issues. Since 1990, it had passed the following rules

- Litter Rule 1990

- Offensive Weapon Carrying Rule 1990

- Animal Keeping Rule 1990

- Fighting in Public Rule 1990

- Pig Trespass Rule 1990

- Street Selling Rule 1990

- Aerodrome Trespass Rule 1990

- Tax Rule 1991

- Disco Control Rule 1991.

However the council had problems with documentation and gazettal of the rules, and it is not clear from the Annual Report which rules, if any, had been gazetted. Even if all rules were gazetted, there was still the problem of finding the manpower to enforce them. 
In 1993, the Porgera council had new council chambers at Paiam, indicating perhaps that the town itself would come under the council's jurisdiction. However, the council did not have adequate staff or finance to undertake its existing functions, even after its works function had been taken over by the PDA. The council needed more permanent staff to manage its affairs and programmes, and some additional temporary staff to tackle outstanding administrative and organisational problems, as well as any new proposed activities.

\section{The Porgera Landowners' Association and Community Issues Committee}

According to the SEIS (Pacific Agribusiness 1987[2]:12), 'the Porgera Landowners' Association [PLA] was formed in January 1986 to represent clans owning land within the SML area, but has since been weakened by conflict between "true" landowners and invited guests who subsequently gained control of the executive for political purposes'. Because of this problem, the Landowners' Negotiating Committee was formed, in early 1987 , specifically to negotiate the compensation and relocation agreements for the SML. The SEIS suggested that 'such single purpose groups are likely to succumb to conflicting purposes once the immediate aim is fulfilled'. In fact, after the agreements were negotiated and signed, the Negotiating Committee continued to meet, and became a successful forum for debating issues and grievances between the PJV and the landowners. The committee then expanded to include the original 23 members and their alternates, plus the nine local councillors who took part in the Development forum and signed the Mining Development Contract. This expanded group was renamed the Community Issues Committee (CIC). This committee was still meeting regularly with the PJV in 1993, and had grown into a responsible and effective group, though this did not mean that the two parties were always in agreement.

Meanwhile, the PLA-which still represented the Porgeran landowners at the quarterly review meetings coordinated by the Department of Mining and Petroleum-was suffering (at least until 1992) from a lack of credibility due to organisational problems. According to its chairman, the PLA only became a registered organisation in 1991 (Nixon Mangape, pers. comm.). In 1992, it became a more professional organisation, and began producing written documents relating to its concerns and demands. 
While I am still unclear as to the structure and membership of the PLA , I assume that it was supposed to represent the interests of all landowners in the Porgera Census Division, not just the SML. In 1993, it appeared that the PLA and the CIC were really one and the same group. In 1992-93, the same person was chairman of both groups, and many of the PLA executives were attending CIC meetings. Issues debated with the PJV were often the same issues presented to the national government at the quarterly review meetings. Therefore, the CIC could be viewed as the unofficial forum for debate, and the PLA as the official body which monitored progress on the conditions of the Porgera forum agreements, as well as the other concerns of Porgeran landowners. This appeared to be a very satisfactory arrangement.

\section{The Christian churches}

The Christian churches in Papua New Guinea have always had an important role in social development. This has included mission-run schools and health services, youth and women's programmes. In addition, all churches bring the basic message of peace and preach against socially disruptive influences such as polygamy, tribal fighting and adultery. In 1962, after Porgera was de-restricted, four Christian denominations entered the valley: Apostolic, Roman Catholic, Seventh Day Adventist and Lutheran. These remain the four main churches in the Porgera District. Gibbs (1977:23) wrote that in 1974 'mission bodies exert a considerable influence, though this is truer in the Paiela valley than in Porgera'. Interviews with church leaders in Porgera indicated that this situation still existed in 1993.

The Apostolic Church was a strong, peaceful influence in the community until the split in its membership in 1992. The breakaway church, led by a couple of Apostolic pastors from Kandep, was called the Apostolic Pentecostal Church of PNG, while the parent church was called the Christian Apostolic Fellowship, and still belonged to the worldwide body of Apostolics. In 1993, this division was causing problems in the Porgera area-especially in Paiam, Kulapi and Anawe-but the influence of the breakaway church had apparently not yet extended to Paiela. One result of the conflict was a court case over who should conduct services at the newly built Paiam Apostolic Church and the closure of the literacy classes at Paiam and Anawe. According to Pastor Patimo Kolape, there were about 1,000 active Apostolic church members in the Porgera District in 1993, and about another 1,000 who had been baptised but were no longer attending services. 
The Lutheran Church came into Porgera District in 1962, and acquired leases at Mungalep, Yuyan, Yendekale and Kolombi (Paiela). The conflict in the Lutheran church in Enga had not affected Porgera, as only the Maramuni church was represented in the district. In 1993, the church had three agency community schools at Yuyan, Porgera Station and Takopa (Paiela). According to Pastor Pes Kiwale, there were between 750 and 950 active church members in the Porgera District. The Roman Catholic Church was based at Mungalep, and was running three community schools at Mungalep, Tipinini and Kolombe (Paiela). According to Father Peter, there were about 2,000 active church members in the district, and the membership was stronger in the Paiela area than in Porgera Census Division itself. The Seventh Day Adventist Church was based at Yendekale. According to Pastor Lambu, there were about 2,000 active members in 1993, and the Adventists had been actively recruiting new members since 1992.

All churches appeared to have gained strength since 1989. However, according to some church leaders, the 1988 Mount Kare gold rush had a very negative impact on their activities. Church leaders also agreed that weekly church attendance and other church activities were more common among women than men. This difference was explained by the fact that men were practising polygamy, which is against the principles of all four churches, and were involved in compensation practices which were contrary to the principles of the Seventh Day Adventist and Apostolic churches. All four churches had very good programmes for youth and women in other parts of Papua New Guinea, but these programmes were very weak in the Porgera District, possibly because of the lack of an educated congregation to implement community programmes.

\section{The Porgera Women's Association}

The Porgera District Women's Association, generally known as the Porgera Women's Association (PWA) or Ipili Wanda Yame, was formed on 18 October 1989. The basis for the association was the small group activities under the PJV's Women's Relocation Programme in the SML and the small number of women's groups which already existed in the district. The association started out with six member groups, but this had increased to 36 by July 1992. Besides the village women's groups (wanda yame), there were separate groups representing Porgera and Paiela government stations, and one group for women employees working at the mine, while the girls 
attending the CODE centre had also formed a group and joined the association. Many, but not all, of the member groups were churchbased groups. Church-based groups were encouraged because these groups generally have greater strength, or greater potential for strength, as they are based on and supported by existing church programmes.

The PWA was an incorporated association managed by a ninewoman executive or management committee which met monthly. General meetings were held monthly for ten months, with a twomonth break over the Christmas period. The association had been recognised and supported by the PJV, the Division of Porgera, the PDA, and the Porgera Local Government Council. It was also a member of the Enga Council of Women.

The initial success of the PWA can be attributed to the social disruption in the community caused by both the Mount Kare gold rush and mining development at Porgera itself. Local women had many problems or issues of common concern. In addition, Porgera society was fluid and flexible in the face of change, and since there had never been any previous attempt to form a district-level women's council in Porgera, there were no historical problems to be overcome. The association also had the support of a few leading Porgeran men who prevented any organised male backlash.

The primary purpose and function of a district-level women's association was to give women the leadership skills and public voice which would enable them to participate in decision making, and eliminate discrimination against half the population, in a world populated by an increasing number of non-traditional, maledominated institutions. Where rapid social change is taking place, as it was in Porgera, a strong women's association is necessary to ensure that women are not further disadvantaged by male decision-makers. In Porgera, the newly created institutions included the PLA, the CIC, the PDA, the Porgera Allied Workers Association, and of course the PJV itself. These were additions to the existing non-traditional institutions, like the provincial government, the local government councils, and the village courts.

A second function of the PWA was to promote relevant formal, nonformal and informal education programmes to meet the needs of women, their families and the wider community. A third function was to identify and promote economic activities-improving subsistence agriculture, business skills and income-generating opportunities for 
women.

The President of the PWA was the elected women's representative on the PDA. ${ }^{24}$ The first project undertaken by the PWA was the successful lobby of the PDA to construct a Women's Resource Centre. Women wanted a building of their own for the association's activities, as well as for prestige. This resource centre was constructed by the PDA using funds from the PJV's Community Facilities Grant. It took one year to progress from project approval to occupancy in mid November 1990. The centre was officially opened on 8 March 1991, as part of the association's Women's Day activities, and was dismantled in May 1991 to prevent its total destruction by the Porgera landslide. The PDA rebuilt the centre next to the existing classrooms at the vocational centre. The resource centre, a modified relocation house, was now too small for the association's needs. The District Manager suggested that, when Paiam town was built, a new and larger Women's Resource Centre should be located there, and the present centre could then be turned over to the vocational centre as a home economics building.

Programmes and projects organised by the PWA from October 1989 to May 1993 included

- International Women's Day celebrations in 1990 and 1991

- lobbying the PDA for the appointment of women as village court magistrates

- a 'Women and Law Day' on 2 October 1991

- the Porgera literacy project

- women's leadership and skills courses

- business awareness and book-keeping courses

- a screen printing project

- an ore sample bag-making business

- a second-hand clothing business

- poultry and vegetable projects; and

- an artefact business.

Some of these programmes and projects were on-going in 1993, and some were one-off affairs. Some were highly successful, while some had problems. ${ }^{25}$

\section{The Porgera Paiela Youth Association}

The Porgera Paiela Youth Association (PPYA) was formed on 28 August 1989. Over the next four years, its affiliation grew from eleven to 51 member groups, approximately half of which were church-based 
groups, and 12 of which were based in Paiela Census Division. The PPYA was specifically formed as an independent youth association outside of the National Youth Movement Programme (NYMP) and the Enga Youth Council. In 1989, the Enga Provincial Youth Council was experiencing many problems, and was dominated by 'grey-bearded' youth-a fact which supported the suspicion that most member groups were in fact not youth groups at all, but family business groups registering with the NYMP in order to access money under the latter's grant scheme. This grant scheme encouraged a 'handout mentality' and an atmosphere of conflict and competition, as opposed to cooperation, between member groups. In addition, there were many groups, especially in the Tipinini area, which had been ripped off by investing in the now defunct National Youth Development Fund which was part of the NYMP.

Youth associations are more complex than women's associations. The first problem is defining just what the term 'youth' means. The 'adolescence' definition of youth is the period between childhood and acceptance of the full responsibilities of adulthood, but this becomes problematic when one considers the early age of marriage in Porgera. When one hears references to the 'youth problem' in Papua New Guinea, the reference is normally to unemployed, out of school, males between the ages of 16 and 25 . A rigid definition of youth simply is not possible if one is trying to develop youth programmes which are integrated into, rather than separate from, the community. In Porgera this problem was tackled by defining 'youth' as people between the ages of 13 and 25. Anyone older was classified as an 'adviser'. In order to register with the PPYA, youth groups had to have more 'youth' members than 'adviser' members.

The second problem is appeal. For example: in areas where women's concerns tend to focus on their roles as mothers and wives, older teenage girls may feel they have more in common with women's groups. At the same time, very 'naughty' male youth are unlikely to join youth groups, while older male 'youth' who are married have a different agenda to younger teenagers. Youth associations are also more vulnerable than women's associations to being manipulated for political purposes.

In order to discourage the 'handout mentality' syndrome associated with grants to youth groups, a Youth Contract Scheme was initiated by the PJV. Under this scheme, youth groups registered with the PPYA undertook labour contracts to earn money. For some reason, this programme lapsed in 1992, but was being revitalised the time 
of the present study.

Youth and women's groups often have money-making projects. The PJV's Youth Coordinator reported that in 199317 youth groups had vegetable projects, 50 had poultry (meat bird) projects, 12 were involved with trade stores, and three with tyre services. There were often unrealistic expectations as to the outcomes of these projects. At best, they offered skill training and a fund-raising source for group activities; at worst, they failed due to lack of knowledge and support or misuse of project funds by a member of the group. The members of the PPYA also wanted a project to give them a 'name'. They decided on a didiman (agricultural supply) store. This was funded by the PDA, and had a government business development officer attached to the project. By 1993, the store, which was located in Porgera market, had expanded to include a bookstore, as well as the sale of agricultural supplies.

Youth training courses to mid 1993 had concentrated on sporting skills (basketball, volleyball, badminton and table tennis), business management skills, and leadership. In 1990, the association organised a law and order rally at Porgera Station, but this was not very successful for a variety of reasons, which included heavy rain. Youth groups and the PPYA were very effective as organisers of the Independence Day celebrations in Porgera, which included a Youth Show. Both the PPYA and the PWA had extensive social networks which had tremendous potential for extension work.

\section{PJV's Community Affairs Division}

The primary function of the Community Affairs Division was to handle all matters relating to relationships between the PJV and landowners in Porgera, as well as the wider community in Enga Province and in the vicinity of the Hides transmission line. In early 1989 , the division consisted of three separate but closely related sections-Community relations, Lands, and Business Development. These three sections were gradually being strengthened and brought up to full divisional status on a par with the other two divisionsProduction and Administration. The elevation of the 'people side' of mining was due to the strong leadership and capabilities of the Community Affairs Manager, Noel Walters. The process was probably also facilitated by the closure of the Bougainville mine in mid 1989, which sent shivers around the mining community, and by the law and order problems in Porgera and along the highway to Lae, which was 
the lifeline of the mine. In early 1989, the company's efforts had been concentrated on land investigation and acquisition, relocation and business development. With the notable exception of business development, which had an office in Wabag, all programmes were aimed at the Porgera Valley. The hijacking of a truck loaded with mine equipment in 1990, near the Kera bridge in Laiagam District, triggered the beginning of a wider community relations programme in Enga Province, and later in the Tari District around the Hides-Porgera power transmission line.

By mid 1993, the Community Affairs Division had a staff of about 85 working in the following sections

- Lands and relocation

- Community relations-Porgera

- Community relations - other (i.e. the rest of Enga Province and the transmission line)

- Business development: Porgera and Wabag

- Social development and women's affairs

- Youth and recreation (i.e. community level as opposed to site services for PJV employees)

- Media unit.

Local community relations staff were recruited to work in their own home areas, for example Porgera, Laiagam, Sirunki, Wabag and Tari.

There is a growing awareness that the lands, community relations and business development functions are an integral component of modern mining development in Papua New Guinea. However, many senior staff in this field (and not just in the PJV) have felt that they are viewed as a necessary evil-heavily supported when there are problems, but ignored and under-resourced at other times. This is to some degree understandable, as expatriate mine developers are in the business of mining - this is their area of training and expertise.

Weaknesses in the government system have forced mining companies to undertake what are traditionally government activities-the most notable being land investigation, land acquisition and business development. Other activity areas, such as welfare services and community development programmes, were gradually added as the need was identified. The reality is that a strong Community Affairs Division staffed with experienced field officers is critical for the short, medium and long-term viability of the mine.

One problem affecting the Community Affairs Division in 1993 was 
inadequate and inappropriate office facilities, with its sections divided between two locations, thus making coordination between staff more difficult. The division's future was also under a cloud because an increase in production costs was forcing the senior management to look for savings in the non-mine production areas. Future concerns also included the sensitive issue of localisation. There would be a need for strong expatriate representation in the Community Affairs Division, though not necessarily in the top position, throughout the life of the mine. If Community Affairs is totally localised there is a danger of senior mine management becoming isolated from the needs, concerns and attitudes in the community. This would have an adverse impact both on the community and on mining operations-as appears to have been the case in Bougainville.

\section{Notes}

1 I am grateful to Glenn Banks for pointing out the general economic characteristics for each stage of this model.

2 The PJV had requested the allocation of 48 residential blocks at Paiam as part of its Home Ownership Programme. This option would most likely be taken up by Porgeran and possibly by Engan employees.

3 For example, it was estimated that $K 500,000$ per annum was required for staff salaries alone, and this figure did not include Item 10 funds needed for hiring cleaning staff.

4 These figures do not include deaths soon after arrival of which the cause was unclear, nor bodies brought in after death. Nor do they include the significant number of Porgeran deaths due to road accidents, tribal fights and murders.

5 Dr Kramer reported that in the African model, one confirmed AIDS case equals $350 \mathrm{HIV}$ positive. If the African model is applicable to Papua New Guinea, then that would indicate a pool of at least 700 HIV positive persons in the Laiagam area by 1993.

6 The reason given for the absence of WIPS at Porgera Community School was that this school was catering for non-Ipili speaking children from Porgera Station. However, my own visit to the school in May 1993 revealed that an estimated 77 per cent of Grade 1 students were Ipili-speakers.

7 I was told that seven of 12 selected from Tipinini Community School were outsiders.

8 The women wanted Tok Pisin literacy as Porgera had so many non-Ipili speakers, while educationists wanted Ipili literacy as most women did not speak Tok Pisin. A compromise was being initiated in 1993.

9 At this time, the boom gate was in operation to control movements into and out of the SML.

10 The Suyan station was the first building to be completed in the PJV 
compound.

11 The Suyan station was the first building to be completed in the PJV compound. The worst area for armed holdups and hijacking was the Kera River area near Laiagam.

12 Village courts were established in 1973 to deal with minor offences and customary disputes. Village court decisions can be appealed in a district court.

13 The task proved to be more time-consuming than I expected, and I cannot say that my information is complete.

14 The 1991 Annual Report did contain some crime statistics, but they were patchy.

15 The cost of the attack in 1992-for losses, repairs and upgrading of the facility - was reputed to be $\mathrm{K} 1$ million.

16 The PDA retained the right to maintain this ban if it were to be lifted by the Enga Provincial Government, but it did not have the power to permit sales and importation during a provincial government ban.

17 Women in Association meetings also alleged that some police were involved with black market alcohol activities-at least on the consumption end.

18 Snooker tables were common in the larger trade stores, and local children had begun making mini-snooker tables where marbles were used in place of snooker balls.

19 The royalty rate has since been raised to 2 per cent of export value.

20 By contrast, the records concerning the 23 per cent share of royalties paid to landowners and community institutions are readily available for public scrutiny.

21 In 1995, the national parliament passed a new Organic Law on Provincial Governments and Local-Level Governments which radically transformed the whole system of provincial government. The impact of these reforms is beyond the scope of this study.

22 The Department of Enga was restructured twice between 1989 and 1993.

23 Sources of revenue for the PDA included a Special Support Grant from the provincial government, Community Facilities Grant from the PJV, and tied grants from both the provincial and national governments.

24 There was only one woman on the CIC, and none on the PLA executive. I was tempted to suggest that there should be more, but I did not hear this demand from the PWA.

25 One problem that had never been successfully resolved was the status of women's groups in Paiela Census Division. There was no Paielan woman on the PWA Management Committee, and there was poor attendance by Paielan members at the general meetings because of the area's remoteness from Porgera. Paielan women indicated that they would like an association of their own. 